\title{
Opportunities for ceria-based mixed oxides versus commercial platinum-based catalysts in the soot combustion reaction. Mechanistic implications.
}

\author{
Javier Giménez-Mañogil and Avelina García-García* \\ MCMA Group, Department of Inorganic Chemistry. Faculty of Sciences. \\ University of Alicante. Ap.99-E-03080 Alicante.SPAIN. (a.garcia@ua.es).
}

\begin{abstract}
The aim of this paper is to study the activities of ceria-zirconia and copper/ceriazirconia catalysts, comparing with a commercial platinum/alumina catalyst, for soot combustion reaction under different gas atmospheres and loose contact mode (simulating diesel exhaust conditions), in order to analyse the kinetics and to deduce mechanistic implications.

Activity tests were performed under isothermal and TPR conditions. The NO oxidation to $\mathrm{NO}_{2}$ was studied as well. It was checked that mass transfer limitations were not influencing the rate measurements. Global activation energies for the catalysed and non-catalysed soot combustion were calculated and properly discussed.

The results reveal that ceria-based catalysts greatly enhance their activities under $\mathrm{NOx} / \mathrm{O}_{2}$ between $425^{\circ} \mathrm{C}$ and $450^{\circ} \mathrm{C}$, due to the "active oxygen"-assisted soot combustion. Remarkably, copper/ceria-zirconia shows a slightly higher soot combustion rate than the Pt-based catalyst (under $\mathrm{NOx} / \mathrm{O}_{2}$, at $450^{\circ} \mathrm{C}$ ).
\end{abstract}

Keywords: Soot combustion kinetics; $\mathrm{NO}_{2}$; activation energy; copper/ceria-zirconia; platinum-based catalyst; active oxygen.

*Corresponding author. Tel.: +34 965909419; e-mail: a.garcia@ua.es

Fax: +34 965903454 


\section{Introduction}

The raise of diesel-engine vehicles in the recent years has consequently increased the concentration of soot particles (PM) and nitrogen oxides (NOx) in the atmosphere. The hazardous effects of these pollutants on our health and the environment have led to strictly regulations in the composition of the diesel exhaust gases, in order to diminish the emissions of soot and NOx [1-4].

Diesel particulate filters (DPFs) are appropriate systems to remove soot particles generated by the diesel engines [5]. DPFs are wall-flow monoliths that need to be regenerated due to the channel blocking produced by soot accumulation. An effective regeneration strategy consists of coating the DPF's walls with an oxidation catalyst in order to oxidise soot to $\mathrm{CO}_{2}$, preferentially.

There are two oxidising gases present in diesel exhaust emissions that are suitable for soot combustion: $\mathrm{O}_{2}$ and $\mathrm{NO}_{2}$. They both play an important role in DPF regeneration. In diesel exhaust emissions, $\mathrm{O}_{2}$ is much more abundant than $\mathrm{NO}_{2}$. However, $\mathrm{NO}_{2}$ is much more active than $\mathrm{O}_{2}$, since it can directly attack the carbon surface. It has been shown that the oxidation of soot by $\mathrm{NO}_{2}$ occurs at typical exhaust temperature of diesel engines $\left(250-400^{\circ} \mathrm{C}\right)$ [2,6-13].

Among the several catalysts used for soot combustion, the most common are: molten salts [14-17], Pt-based oxides [18-21], ceria-based oxides [18,19,22-28], and others based on transition metals (such as copper or iron) [20,24,26,29-34]. Although those catalysts containing Pt show a very high activity in the $\mathrm{NO}$ oxidation to $\mathrm{NO}_{2}$ (and thus, promoting soot combustion), some other catalysts are being developed, whose $\mathrm{NO}_{2}$ production activities are becoming closer to those of Pt-based catalysts, but with lower costs.

However, the $\mathrm{NO}$ to $\mathrm{NO}_{2}$ oxidation capacity does not match linearly to the soot combustion rate, because there are some other factors that influence this reaction, such as lattice oxygen mobility and production and transfer of “active oxygen”, as reported in the literature for ceria-based catalysts [22,35]. In a recent preliminary study [36], the 
rate of soot combustion under isothermal conditions at $400^{\circ} \mathrm{C}$ shown by a copper-doped ceria-zirconia catalyst was very high, and only a little bit lower than that of a commercial Pt-catalyst in terms of mass of catalyst, but higher if the activity was expressed in terms of price of catalyst.

Even though a large number of catalytic formulations have been tested for the catalytic combustion of diesel soot, a lot of work is still needed in order to advance towards a rational catalyst design. To get information regarding each catalyst component's role, intrinsic reaction rates must be evaluated. Consequently, mass transfer limitation phenomena must be minimised. Working under realistic soot-catalyst contact (loose contact) implies that mass transfer limitations could become very important, thus decreasing the overall reaction rate. For this reason, the tight contact mode has been widely used to obtain kinetic data of the catalytic soot combustion [3739]. However, it is necessary to obtain reaction rates under loose contact in order to determine intrinsic kinetics to achieve an efficient design and operation of the DPFcoated system.

Numerous researchers have conducted experiments to define the kinetics associated to soot combustion, but the activation energy values reported present discrepancies, because they can be quite dependent on the experimental conditions, mainly the gaseous atmosphere used, due to the synergic effects among the gaseous reactants and the type of contact among the soot and the catalyst particles [28, 40].

Therefore, a comprehensive analysis is required to accurately evaluate kinetic parameters under loose contact conditions with very active soot combustion catalysts, presenting acceptable reaction rates at temperatures close to those of the diesel exhaust.

In order to shed more light on this matter, the present study analyses the performance of two very active ceria-based catalysts (undoped and copper-doped catalysts) as well as a commercial Pt/alumina catalyst in a set of experiments (under isothermal/ramp modes and under different gas atmospheres) to explore the opportunities of ceria-based catalysts versus the noble-metal supported catalyst for the soot combustion application. The combustion assisted by $\mathrm{NO}_{2}$, by "active oxygen" as 
well as the $\mathrm{NO} \leftrightarrow \mathrm{NO}_{2}$ recycling efficiency of the catalysts were analysed. The selection of the most appropriate experimental conditions to obtain reliable kinetic data was carried out. The results obtained from the kinetic study and the mechanistic implications derived from the whole experimental results were properly discussed.

The aim of this paper is to conduct a systematic study of the ceria-based catalysts' activities for soot combustion, comparing to a commercial platinum/alumina catalyst, in order to justify the different catalytic behaviours under different atmospheres. Since the selected catalysts are very active for soot combustion, it is possible to obtain reliable kinetic parameters under realistic diesel exhaust conditions (loose contact and temperature). To carry out this approach, it is important to verify in a preliminary study that the reaction is controlled by chemical regime and activity measurements are reproducible.

\section{Material and methods}

\subsection{Catalysts preparation}

The $\mathrm{Ce}_{0.8} \mathrm{Zr}_{0.2} \mathrm{O}_{2}$ mixed oxide (denoted as $\mathrm{CZ}$ ) was synthesised by the coprecipitation method in alkaline medium, by using the cerium and zirconium precursors $\left(\mathrm{NH}_{4}\right)_{2} \mathrm{Ce}\left(\mathrm{NO}_{3}\right)_{6}$ (supplied by Panreac with $99.0 \%$ purity) and $\mathrm{ZrO}\left(\mathrm{NO}_{3}\right)_{2} \cdot \mathrm{xH}_{2} \mathrm{O}$ (supplied by Sigma-Aldrich, with $\mathrm{x} \approx 6$, technical grade), respectively. The appropriate amounts of these precursors were dissolved in distilled water. The corresponding hydroxides of cerium and zirconium were co-precipitated by dropwise addition of a $10 \%$ ammonia solution in water until $\mathrm{pH}=9$, under constant stirring. The solid obtained was then filtered under vacuum and the yellowish precipitate was washed with distilled water until neutral $\mathrm{pH}$. Finally it was dried overnight at $110^{\circ} \mathrm{C}$ and calcined in air in a muffle at $500^{\circ} \mathrm{C}$ for $1 \mathrm{~h}$, with a heating rate of $10^{\circ} \mathrm{C} / \mathrm{min}$.

The $\mathrm{Ce}_{0.8} \mathrm{Zr}_{0.2} \mathrm{O}_{2}$-supported catalyst with $\mathrm{Cu} 2 \mathrm{wt} \%$ (denoted as $\mathrm{Cu} 2 / \mathrm{CZ}$ ) was prepared by incipient wetness impregnation with an aqueous solution of $\mathrm{Cu}\left(\mathrm{NO}_{3}\right)_{2} \cdot 3 \mathrm{H}_{2} \mathrm{O}$ (supplied by Panreac with $99.0 \%$ purity). After impregnation, the sample was dried overnight in an oven at $110^{\circ} \mathrm{C}$ and thereafter calcined under air at 
$500^{\circ} \mathrm{C}$ for $1 \mathrm{~h}$, with a heating rate of $10^{\circ} \mathrm{C} / \mathrm{min}$. The actual copper content on the catalyst was close to the nominal value, as verified by ICP-OES (Perkin Elmer, Optima 3000). The copper was extracted from the catalyst using a mixture of concentrated $\mathrm{HCl} / \mathrm{HNO}_{3}$ (3/1 ratio). For comparative purposes in selected experiments, another catalyst with $\mathrm{Cu} 6 \mathrm{wt} \%$ (denoted as $\mathrm{Cu} 6 / \mathrm{CZ}$ ) was prepared by the same method.

The commercial $1 \% \mathrm{Pt} / \mathrm{Al}_{2} \mathrm{O}_{3}$ catalyst (denoted as $\mathrm{Pt} 1 / \mathrm{AL}$ ) was supplied by SigmaAldrich.

The three representative catalysts present a very similar average crystal size, determined by XRD (around $6 \mathrm{~nm}$ ). A complete physico-chemical characterisation of them was reported elsewhere [36].

\subsection{Catalytic activity}

\subsubsection{Temperature Programmed Reactions ( $\mathrm{NO}$ to $\mathrm{NO}_{2}$ oxidation and soot combustion)}

The catalytic tests were performed in a tubular quartz reactor coupled to specific NDIR-UV gas analysers (Fisher-Rosemount, models BINOS 100, 1004 and 1001) for $\mathrm{CO}, \mathrm{CO}_{2}, \mathrm{NO}, \mathrm{NO}_{2}$ and $\mathrm{O}_{2}$ monitoring. For the $\mathrm{NO}$ oxidation tests, $80 \mathrm{mg}$ of catalyst were diluted with $320 \mathrm{mg}$ of $\mathrm{SiC}$ to avoid pressure drop. The gas mixture used

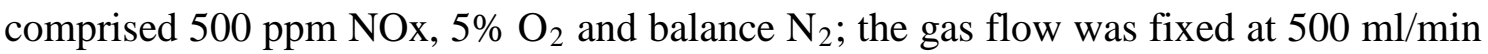
$\left(\mathrm{GHSV}=30,000 \mathrm{~h}^{-1}\right)$. The experimental set-up has been designed in order to ensure that the proportion of $\mathrm{NO}_{2}$ in the $\mathrm{NO}+\mathrm{O}_{2}$ mixture fed to the reactor is negligible. The catalytic tests consisted of temperature programmed reactions, where the temperature was increased from room temperature up to $700^{\circ} \mathrm{C}$ at $10^{\circ} \mathrm{C} / \mathrm{min}$ under the reactive atmosphere, with the purpose of quantifying the $\mathrm{NO}$ to $\mathrm{NO}_{2}$ oxidation capacity of the catalysts.

The $\mathrm{NO}_{2}$ production profiles were determined in relation to the total amount of $\mathrm{NOx}$ as a temperature function using the following expression (equation 1):

$$
\mathrm{NO}_{2}(\%)=100 \cdot\left(N O_{2} \text { output }\right) /\left(N O_{\text {output }}+N O_{2 \text { output }}\right)
$$


where $\mathrm{NO}_{\text {output }}$ and $\mathrm{NO}_{\text {2output }}$ are the $\mathrm{NO}$ and $\mathrm{NO}_{2}$ concentrations, respectively, measured at the reactor exit.

Soot combustion under temperature programmed conditions was conducted with a heating rate of $10^{\circ} \mathrm{C} / \mathrm{min}$ from room temperature to $700^{\circ} \mathrm{C} .80 \mathrm{mg}$ of catalyst were mixed with $20 \mathrm{mg}$ of Printex-U soot (supplied by Evonik-Degussa) in loose contact conditions [41], diluted with $300 \mathrm{mg}$ of $\mathrm{SiC}$ (to avoid pressure drop and favour heat transfer), and placed in the reactor. Two different atmospheres were used to carry out the TPR experiments: i) under $\mathrm{NOx} / \mathrm{O}_{2}$, the gas mixture comprised $500 \mathrm{ppm} \mathrm{NOx,5 \%}$ $\mathrm{O}_{2}$ and balance $\mathrm{N}_{2}$; ii) under $\mathrm{O}_{2}$, the gas mixture comprised $5 \% \mathrm{O}_{2}$ and balance $\mathrm{N}_{2}$. Besides, the uncatalysed reaction was tested as well under $500 \mathrm{ppm} \mathrm{NO}_{2}, 5 \% \mathrm{O}_{2}$ and balance $\mathrm{N}_{2}$. The gas flow was fixed at $500 \mathrm{ml} / \mathrm{min}$ in all cases $\left(\mathrm{GHSV}=30,000 \mathrm{~h}^{-1}\right.$ ).

\subsubsection{Isothermal reactions and mass transfer limitations analysis}

Soot combustion tests were performed with the catalysts in isothermal mode $\left(400^{\circ} \mathrm{C}\right.$, $425^{\circ} \mathrm{C}$ and $450^{\circ} \mathrm{C}$ ) under $\mathrm{NOx} / \mathrm{O}_{2}$, in the same experimental conditions than those described above.

Soot combustion reaction yields to the formation of two possible products: $\mathrm{CO}$ and $\mathrm{CO}_{2}$. Selectivity to $\mathrm{CO}_{2}$ formation (equation 2) is also an important parameter that was determined by using the expression:

$$
\text { Selectivity to } \mathrm{CO}_{2}(\%)=100 \cdot\left(\mathrm{CO}_{2}\right) /\left(\mathrm{CO}+\mathrm{CO}_{2}\right)
$$

where $\mathrm{CO}$ and $\mathrm{CO}_{2}$ are the $\mathrm{CO}$ and $\mathrm{CO}_{2}$ concentrations, respectively, measured at the reactor exit.

Since the aim of comparing intrinsic catalytic activities is to work under a kinetic controlled regime, a fundamental aspect to take into account is the absence of mass transfer limitations. In the particular case of soot combustion reaction, only external mass transfer limitations can take place since only the external catalytic surface may be in contact with the soot. In order to verify that there are no external mass transfer limitations, different sets of experiments were carried out. The criterion was based on 
conducting rate measurements varying the experimental conditions. For this purpose, Koros-Nowak test modified by Madon-Boudart was employed [42]. CZ was chosen as a representative catalyst to check if mass transfer phenomena were significantly influencing the soot combustion reaction. These experiments were conducted in isothermal conditions at $450^{\circ} \mathrm{C}$, under $\mathrm{NOx} / \mathrm{O}_{2}$. Two sets of experiments were performed:

- Experiments where the space velocity (GHSV) was kept constant by varying in the same ratio the gas flow and the amount of solids in the reactor, and thereby changing the bed volume proportionally (experiments designated as A1, A2 and A3).

- Experiments where only the catalyst mass was modified (A1 and B1).

Table 1 shows the summary of the employed conditions.

On the other hand, given the high exothermicity of the soot combustion reaction, a reaction runaway could take place [43]. In this sense, possible local heating in the catalytic bed due to the heat generated during the reaction was avoided by placing SiC in the reactor. Under these experimental conditions, the catalytic bed temperature monitoring along the temperature programmed soot combustion reaction is similar to that followed along the NO oxidation reaction, confirming that no significant energy transfer limitations are taking place.

\section{Results and discussion}

\subsection{Mass transfer limitations analysis}

In order to establish that the measurements are not influenced by external mass transfer phenomena, Koros-Nowak test modified by Madon-Boudart has been carried out, considering a differential reactor [42].

A set of experiments (denominated A1, A2 and A3) has been conducted maintaining constant the space velocity in the reactor, as explained in Section 2.2.2. If the space velocity is kept constant, Koros-Nowak criterion is obeyed if the observed conversion is invariant [42]. Figure 1 depicts the activity curves obtained from A1, A2 and A3 experiments (see Table 1). Soot combustion rate is expressed as $\mathrm{mg}_{\text {soot }} \cdot \mathrm{s}^{-1} \cdot \mathrm{g}_{\text {catalyst }}{ }^{-}$ ${ }^{1} \cdot \mathrm{g}_{\text {initial soot }}{ }^{-1}$ for a reliable comparison. The corresponding isothermal profiles are quite 
similar for A1, A2 and A3, thus revealing that Koros-Nowak criterion is obeyed and therefore mass transfer effects are not significant under these experimental conditions.

On the other hand, another set of experiments (A1 and B1) have been conducted by modifying only the concentration of the catalytically active material. It is expected that combustion rate changes proportionally to the catalyst mass in the kinetic regime. Figure 2 shows the isothermal curves at $450^{\circ} \mathrm{C}$ for the experiments $\mathrm{A} 1$ and $\mathrm{B} 1$. Soot combustion rate approximately decreases in a $3 / 4$ ratio, from $0.18 \mathrm{mg}_{\text {soot }} \cdot \mathrm{s}^{-1} \cdot \mathrm{g}_{\text {initial soot }}{ }^{-}$ ${ }^{1}$ (for $80 \mathrm{mg}$ of catalyst), to 0.12 (for $60 \mathrm{mg}$ of catalyst), when conversion is $20 \%$. This ratio is observed for any conversion considered, with small deviations.

Taking into consideration all these results, it can be confirmed that mass transfer effects are not influencing significantly our measurements under isothermal conditions at $450^{\circ} \mathrm{C}$. Therefore, it can be assumed that mass transfer limitations will be irrelevant at the lower temperatures $\left(400^{\circ} \mathrm{C}\right.$ and $\left.425^{\circ} \mathrm{C}\right)$.

\subsection{TPR experiments}

Soot combustion profiles versus temperature obtained in selected combustion experiments, carried out with the commercial Pt-catalyst along with the ceria-containing catalysts ( $\mathrm{CZ}$ and $\mathrm{Cu} 2 / \mathrm{CZ}$ ), are shown on Figure 3. Whatever the temperature range considered, the commercial Pt catalyst is always more active than the ceria-containing catalysts under $\mathrm{NOx} / \mathrm{O}_{2}$. Cu2/CZ catalyst shows better response in the range of lower temperatures regarding $\mathrm{CZ}$, while their activities are very similar in the range of higher temperatures.

The corresponding non-catalysed soot combustion under $\mathrm{NO}_{2} / \mathrm{O}_{2}$ is also shown on Figure 3. It can be seen that the existent loose contact between catalyst and soot accelerates the soot combustion reaction in a superior way than a $\mathrm{NO}_{2} / \mathrm{O}_{2}$ stream would produce; the latter would simulate an efficient Diesel Oxidation Catalyst in a CRT system. In other words, a constant $\mathrm{NO}_{2} / \mathrm{O}_{2}$ stream (500 ppm $\mathrm{NO}_{2}$ and $5 \% \mathrm{O}_{2}$ ) passing through the soot bed cannot be the sole explanation for the catalytic behaviour of the selected samples, because if so, the curves would be superimposed (or that 
corresponding to the non-catalysed $\mathrm{NO}_{2} / \mathrm{O}_{2}$ combustion moved towards lower temperatures).

The corresponding soot combustion curves under a NO-free atmosphere (only containing $5 \% \mathrm{O}_{2}$ ) are illustrated on Figure 4. The order of activity is quite different to that found under $\mathrm{NOx} / \mathrm{O}_{2}$ and now the Pt-based catalyst is the least active of the set of catalysts and the other two catalysts $(\mathrm{CZ}$ and $\mathrm{Cu} 2 / \mathrm{CZ})$ present very similar soot conversion curves. As expected, these three curves are shifted towards higher temperatures in the NO-free stream, due to the absence of the $\mathrm{NO}_{2}$-assisted soot combustion.

In order to explore the specific mechanisms that take part in the catalytic oxidation of soot, thus explaining the superior activity of the studied catalysts under $\mathrm{NOx} / \mathrm{O}_{2}$ with regard to the non-catalysed $\mathrm{NO}_{2} / \mathrm{O}_{2}$ combustion, Figure 5 shows the evolution of the $\mathrm{NO}_{2}$ production profiles during blank experiments and Figure 6 illustrates the same profiles obtained from the soot combustion experiments under $\mathrm{NOx} / \mathrm{O}_{2}$ (curves of $\mathrm{NO}_{2}$ slip). It is interesting to note that even though the soot combustion is seen considerably accelerated in the case of the Pt-catalyst, the difference between the $\mathrm{NO}_{2}$ blank profile and the $\mathrm{NO}_{2}$ slip profile is very small (4\% in the maximum, approximately), if it is compared with the corresponding differences measured for the other two ceria-based catalysts. These ideas, joined to the lowest activity shown by the Pt-containing catalyst under $\mathrm{O}_{2} / \mathrm{N}_{2}$ stream, lead to assess that the high activity towards soot combustion originated by the noble metal catalyst is not only due to its highest $\mathrm{NO}_{2}$ production during a blank experiment. This high activity is also attributed to the high efficiency of the commercial Pt-catalyst to recycle the NO molecules derived from the $\mathrm{NO}_{2}$-soot reaction again to $\mathrm{NO}_{2}$ along the catalyst-soot bed.

However, and very importantly, the capacity of the two ceria-based catalysts to recycle efficiently the NO molecules along the catalytic reactor, if any, is moderate. Anyway, the $\mathrm{NO}_{2}$ production in the loose contact mode (between catalyst and soot) is not the rate-limiting step under our experimental conditions, since $\mathrm{NO}_{2}$ slip always emerges whatever the temperature range investigated. 
Discussing now the benefits of doping ceria-zirconia with copper towards soot combustion, it is worth noting that $\mathrm{Cu}$ conveniently accelerates the $\mathrm{NO}$ oxidation reaction, mainly at low temperatures, thus promoting the soot combustion reaction in the low-medium temperature range compared to the undoped ceria-zirconia. Nevertheless and as a consequence of the contribution of "active oxygen”-assisted soot combustion [44], both curves become very similar at high temperatures (Figure 3).

On the other hand, it has been properly proved that a high loading of copper, with concomitant decrease in surface area and existence of crystalline/large entities of $\mathrm{CuO}_{\mathrm{x}}$ on ceria-zirconia's surface inhibits the "active oxygen"-assisted soot combustion; this effect is observed for the Cu6/CZ sample, included on Figure 4. It was checked under $\mathrm{O}_{2} / \mathrm{N}_{2}$ stream, where the two main mechanisms contribution can be properly split up. Therefore, the $2 \% \mathrm{Cu}$ loading is seen as an optimum amount of metal to accelerate the NO oxidation reaction, thus promoting the soot conversion rate, but it is not high enough to inhibit the "active oxygen”-assisted soot combustion.

Additionally, copper seems not to be beneficial in terms of $\mathrm{NO} \leftrightarrow \mathrm{NO}_{2}$ recycling activity, since $\mathrm{NO}_{2}$ slip production is low and similar for both ceria-containing catalysts compared to the Pt-catalyst (Figure 6).

To summarise this section, Table 2 presents some activity data estimated from TPR curves under different atmospheres: $\mathrm{NOx} / \mathrm{O}_{2}, \mathrm{NO}_{2}$ and $\mathrm{O}_{2}\left(\mathrm{~T}_{\text {onset }}, \mathrm{T}_{5}, \mathrm{~T}_{50}\right.$, Selectivity to $\mathrm{CO}_{2}$ ). Considering the selectivity to $\mathrm{CO}_{2}$ production, all the non-catalysed reactions yield selectivities among 35\% and 60\%. In contrast, whatever the catalyst used, the selectivity is $85 \%$ or higher; even reaching $100 \%$ in some cases. In general terms, selectivity to $\mathrm{CO}_{2}$ using catalysts is better in $\mathrm{O}_{2}$ than in $\mathrm{NOx} / \mathrm{O}_{2}$, as previous studies pointed out [45].

All the catalysts dramatically decrease the onset temperature for soot combustion (Table 2) under $\mathrm{NOx} / \mathrm{O}_{2}$ in comparison to the corresponding non-catalysed (NC) reaction. The lowest onset temperature is found for Pt1/AL, followed by Cu2/CZ and CZ. In addition, catalysts also decrease the onset temperature for soot combustion under $\mathrm{O}_{2}$. When comparing temperatures of a $5 \%$ of conversion, the three catalysts have 
approximately the same value; but moving to a $50 \%$ of conversion, the copper-doped catalyst becomes the best one, followed by $\mathrm{CZ}$, and finally the platinum-based one.

Finally, non-catalysed combustion under $\mathrm{NO}_{2}$ shows a very low onset temperature, thus confirming the importance of this molecule as an oxidising agent in this process. These results are in perfect agreement with previously reported data [44], where the $\mathrm{NO}_{2}$ production capacity of a catalyst is revealed as crucial for initiating and continuing the soot combustion process under $\mathrm{NOx} / \mathrm{O}_{2}$.

\subsection{Isothermal reaction experiments}

Soot combustion reactions in isothermal conditions were carried out for the catalysts studied, and corresponding combustion rate profiles versus conversion are depicted on Figures $7 \mathrm{a}, 7 \mathrm{~b}$ and $7 \mathrm{c}$, for $400^{\circ} \mathrm{C}, 425^{\circ} \mathrm{C}$ and $450^{\circ} \mathrm{C}$, respectively. Due to the very different reaction times to achieve the same values of conversions, the soot oxidation rates can be best compared as a function of the conversion data. At $400^{\circ} \mathrm{C}, 425^{\circ} \mathrm{C}$ and $450^{\circ} \mathrm{C}$, maximum oxidation rates were achieved for $10-30 \%$ of soot conversion. Whatever the reaction temperature tested, the selectivity values were close to $100 \%$. It is worthwhile to note that the combustion reaction essentially stopped at approximately $60-70 \%$ of soot conversion, after that, the soot oxidation rate was so low that the $\mathrm{CO}_{2}$ emission level monitored by the analyser was that of the residual level of measurement. This is the reason why the profiles were not represented until $100 \%$ of conversion. Similar considerations related to soot combustion isothermal reactions have been described in the literature for different catalytic systems [14].

The activity curves show a parabolic shape: at the beginning of the reaction, the combustion rate increases up to around $10 \%$ of soot conversion; after this, steady state conditions are reached and the rate is kept constant for a period of time. Finally, the rate decreases progressively until the end of the experiment. This type of profile is similar to that described for several authors referred to the uncatalysed diesel soot combustion [46]. 
At $400^{\circ} \mathrm{C}$ and $425^{\circ} \mathrm{C}$ the same trends in catalysts' activity are found and are similar to those found in TPR experiments in this temperature range. However, and remarkably, the activity for $\mathrm{Cu} 2 / \mathrm{CZ}$ catalyst at $450^{\circ} \mathrm{C}$ is slightly higher than the platinum-based one, changing the normal trend in activity, and thus showing a promising possible application of this formulation in diesel exhaust after-treatment systems. All these results highlight the importance of conducting experiments under isothermal conditions, at different temperatures, to complete the studies obtained from Temperature Programmed conditions.

Furthermore, for a deeper analysis, isothermal soot combustion profiles are depicted, separately, on Figures 8a, $8 \mathrm{~b}$ and 8c, for each catalyst. It is important to underline that the platinum catalyst (Figure 8c) shows a gradual and proportional increase in combustion rate with the temperature; meanwhile, combustion rates for ceria-based catalysts increase dramatically from $425^{\circ} \mathrm{C}$ to $450^{\circ} \mathrm{C}$. It can be suggested that other contributions to the reaction mechanism could be relevant when increasing the reaction temperature from 425 to $450^{\circ} \mathrm{C}$. Since there are evidences of "active oxygen"-assisted soot combustion for ceria-based catalysts (see Figure 4), it is reasonable to assert that one of the possible causes explaining the wider difference in rates could be that this temperature $\left(450^{\circ} \mathrm{C}\right)$ is high enough to promote the participation of the "active oxygen" in the soot combustion reaction.

In order to shed more light on these observed trends, corresponding $\mathrm{NO}_{2}$ slip curves obtained from isothermal reactions are illustrated on Figure 9. Taking into account that the $\mathrm{NO}$ oxidation reaction to $\mathrm{NO}_{2}$ is disfavoured with temperature (see thermodynamic equilibrium on Figure 5) and that the soot combustion rate with $\mathrm{NO}_{2}$ increases with the temperature, the trend observed (for the Pt-catalyst) of decreasing the levels of $\mathrm{NO}_{2}$ slip with the reaction temperature is the expected one. However, for the ceria-containing catalysts this trend is not followed. It can be suggested that a concomitant decomposition of nitrite/nitrate species, generated during the $\mathrm{NOx} / \mathrm{O}_{2} /$ soot reaction is affecting their $\mathrm{NO}_{2}$ slip profiles. As a consequence, a possible role of this decomposition process in the kinetics of soot combustion when increasing the reaction temperature from 425 to $450^{\circ} \mathrm{C}$ cannot be neglected. Actually, Atribak et al. provide evidences about the NOx adsorption-desorption mechanism on ceria-zirconia [47]. 
According to these authors, TPD results after $\mathrm{NO}+\mathrm{O}_{2}$ adsorption at $350^{\circ} \mathrm{C}$ reveal that the maximum NOx desorption for ceria-zirconia catalyst ranges between 425 and $450^{\circ} \mathrm{C}$.

\subsection{Kinetic parameters}

The isothermal combustion reactions performed at different temperatures were used to determine the global activation energies $\left(E_{a}\right)$. Even though the kinetics involved in the soot combustion are very complex, simplified models can still be used to obtain a good global representation of the system and it is possible to estimate the global activation energy parameter. The power law kinetic expression chosen is that reported by Gross et al. [23,37]:

$$
\ln (r)=\ln (A)+\ln (f(C, P))+E_{a} / R \cdot 1 / T
$$

where ' $r$ ' is the reaction rate; ' $A$ ' is the pre-exponential factor; ' $f(C, P)$ ' is a function that includes the dependence of the reaction rate with soot concentration, gas partial pressures, and soot particle geometry; ' $E_{a}$ ' is the global activation energy; ' $R$ ' is the gases universal constant; and ' $T$ ' is the absolute temperature.

The global activation energy can be obtained using the set of soot combustion reactions at $400^{\circ} \mathrm{C}, 425^{\circ} \mathrm{C}$ and $450^{\circ} \mathrm{C}$, and measuring the reaction rate at the same conversion level.

Experimental values of the reaction rate obtained at $20 \%$ conversion for the three catalysts studied are plotted as a function of $(1 / \mathrm{T})$ in Figure 10, exhibiting a reasonable linear fit. This level of conversion was chosen since it is representative of steady state conditions (see Figures 7a, 7b and 7c) [21]. It is worthwhile to mention that the whole combustion profile is quite reproducible, as demonstrated on Figure $7 \mathrm{c}$ for a representative catalyst (dotted line, Pt1/AL). The activation energies obtained from these Arrhenius plots (Figure 10) exhibit differences between the catalysts. The 
tendency of activation energies is in agreement with the catalytic activity results, where it was shown that the platinum catalyst is the most active one (in general terms), and correspondingly, the one with the lowest activation energy. This will be properly discussed later.

To check the dependence of the kinetic parameters with the soot conversion level, Table 3 compiles the global activation energy values, calculated for the three catalysts at different conversion levels. It is important to point out that this dependency on the conversion levels has been properly analysed in the literature for tight contact conditions, but it has been studied less extensively in loose contact conditions. The data reveal that the $E_{a}$ parameter is slightly influenced by the conversion level as predicted by the kinetic model. Whatever the conversion percentage considered, the energy values follow the same trend: Pt1/AL catalyst presents the lowest values, followed by $\mathrm{Cu} 2 / \mathrm{CZ}$ and finally CZ. Interestingly, the largest deviations in the activation energies when increasing the conversion level are for the $\mathrm{CZ}$ catalyst. These experimental evidences are in good agreement with the idea that the "active oxygen"-assisted soot combustion will be decisive for this mixed oxide, taking into account that this catalyst presents the lowest capacity to produce $\mathrm{NO}_{2}$. Therefore, combustion process will be particularly affected by the degree of contact between this catalyst and the soot, which will become worse and worse when increasing the conversion.

Finally, it is useful the comparison with literature data in order to check the reliability of the simplified model used and subsequent data estimated. Kinetic parameters of catalysed and non-catalysed soot combustion have been determined in numerous studies mostly using fixed bed reactor (FBR) or thermogravimetric (TG) methods. For comparative purposes, it is interesting to mention the values of $E_{a}$ obtained from uncatalysed combustion of Printex- $\mathrm{U}$ under $\mathrm{O}_{2}$ reported by Yerezets et al. (in the range of carbon conversion of 20-30\%) [48], who found a value of 133 $\mathrm{kJ} / \mathrm{mol}$, which is very congruent with that reported by Zouaoui et al. of $135 \mathrm{~kJ} / \mathrm{mol}$ (using Vulcan soot) [28]. In addition, Stanmore et al. reported an activation energy range of $102-210 \mathrm{~kJ} / \mathrm{mol}$ for this reaction [2]. On the other hand, under $\mathrm{NOx} / \mathrm{O}_{2}$, Azambre et al. reported $132 \mathrm{~kJ} / \mathrm{mol}$ of activation energy [18], and a value of $151 \mathrm{~kJ} / \mathrm{mol}$ was reported by Kalogirou et al. [49]. Our uncatalysed Printex-U combustion under $\mathrm{O}_{2}$ 
and under $\mathrm{NOx} / \mathrm{O}_{2}$ yielded values of $124 \mathrm{~kJ} / \mathrm{mol}$ and $111 \mathrm{~kJ} / \mathrm{mol}$, respectively, which are in reasonable agreement with reported values.

Taking into account that the uncatalysed soot combustion reaction with Printex-U under $\mathrm{NOx} / \mathrm{O}_{2}$ (and $\mathrm{O}_{2}$ ) does not proceed in an appreciable manner at the temperatures of interest of the isothermal studies, activation energies were estimated, from an empirical and very simplified approach, considering differential reactor model at very low conversion levels (TPR mode). From the premises that non-catalysed $E_{a}$ values are congruent with those published in the literature, activation energy values for all the catalysts studied were obtained using this procedure and collected in Table 2 . It is important to highlight that the values for the three selected catalysts are in accordance with those results obtained from the set of isothermal reactions (see Table 3).

The lowest $E_{a}$ value in our studies was found to be $43 \mathrm{~kJ} / \mathrm{mol}$ and corresponds to that obtained under $\mathrm{NO}_{2} / \mathrm{O}_{2}$ atmosphere. This is in agreement with other authors, such as Stanmore et al. [2], who found similar activation energy for this reaction (50 kJ/mol), Kandylas et al. [50], who reported $40 \mathrm{~kJ} / \mathrm{mol}$, and also Lee et al., reporting $44 \mathrm{~kJ} / \mathrm{mol}$ [40]. This fact is in accordance with the idea that $\mathrm{NO}_{2}$ is much more active than $\mathrm{O}_{2}$ and can directly attack the carbon surface [28]. Actually, the activation energy measured for the direct soot- $\mathrm{NO}_{2}$ reaction is very similar to that obtained from platinum-catalysed reaction under $\mathrm{NOx} / \mathrm{O}_{2}$ [21], (consistent values from TPR and isothermal conditions). These results confirm the idea that the relevant reaction pathways influencing the soot combustion rate for the case of Pt are the $\mathrm{NO}_{2}$ net production and/or recycling of NO$\mathrm{NO}_{2}$, being the "active oxygen"-assisted soot contribution much less important (see Figure 4).

Table 4 compiles information about activation energies for the catalysed soot combustion reported in the literature. Some representative activation energies are: 72 and $77 \mathrm{~kJ} / \mathrm{mol}$, for ceria and ceria-zirconia (under $\mathrm{NOx} / \mathrm{O}_{2}$ ), and 135 and 138-149 $\mathrm{kJ} / \mathrm{mol}$ (under $\mathrm{O}_{2}$ ), respectively $[18,27,28]$. By comparing with our results, these values are close to those found for $\mathrm{CZ}$ under $\mathrm{NOx} / \mathrm{O}_{2}$ and $\mathrm{O}_{2}$. $\mathrm{Cu} 2 / \mathrm{CZ}$ catalyst improves the global activation energy under $\mathrm{NOx} / \mathrm{O}_{2}$, but not under $\mathrm{O}_{2}$, with regard to $\mathrm{CZ}$, since finely dispersed copper species onto ceria-zirconia support enhance catalytic activity 
towards $\mathrm{NO}$ oxidation to $\mathrm{NO}_{2}$ that contributes to soot combustion process, as reported in a previous paper [36]. On the other hand, results presented for platinum-based catalysts from the literature show an $E_{a}$ of $107 \mathrm{~kJ} / \mathrm{mol}$ or higher (Table 4) $[18,20]$.

In general, the kinetics of catalysed and non-catalysed soot oxidation present a wide range of activation energies depending on the atmosphere used. And particularly, for the case of catalysed reactions, there is an important dependence on the type of contact. Moreover, as reported by Zouaoui et al. for soot combustion catalysed by ceria [28] (see Table 4), the difference in activation energies between loose and tight contact conditions is more dramatic under $\mathrm{O}_{2}$ (from $135 \mathrm{~kJ} / \mathrm{mol}$ in loose contact to $44 \mathrm{~kJ} / \mathrm{mol}$ in tight contact) than under $\mathrm{NOx} / \mathrm{O}_{2}$ (from $72 \mathrm{~kJ} / \mathrm{mol}$ in loose contact to $59 \mathrm{~kJ} / \mathrm{mol}$ in tight contact). A similar behaviour was pointed out by other authors, such as Oliveira et al. [25]. In the case of tight contact under $\mathrm{O}_{2}$ atmosphere, “active oxygen” reaches easily the soot surface and contributes to the acceleration of the oxidation rate, thus explaining the remarkable difference between loose and tight conditions [28]. Under $\mathrm{NOx} / \mathrm{O}_{2}$, $\mathrm{NO}_{2}$-assisted soot combustion takes place, reducing the differences observed between both types of contact.

\section{Conclusions}

Two mixed oxides (ceria-zirconia and 2\%CuO/ceria-zirconia) have been synthesised and compared to a commercial platinum/alumina catalyst. These solids have been studied for the soot combustion reaction in order to obtain information about their catalytic activities. The large variety of experiments conducted in this study (isothermal at different temperatures/ramp modes, different gas atmospheres) and the proper comparison with the uncatalysed soot combustion have allowed us to gain insight into the reasons of the satisfactory behaviours of the ceria-based catalysts, to analyse the kinetics of soot combustion and to deduce interesting mechanistic implications.

Firstly, a preliminary study carried out by varying the experimental conditions, confirmed that the rate measurements were not influenced by mass transfer limitations, 
allowing us to report reliable kinetic parameters for the soot combustion reaction under realistic loose contact between soot-catalyst.

Secondly, the ceria-based catalysts were very active in loose contact conditions, due to the contribution of the "active oxygen"-assisted soot combustion, which caused a significant enhancement in their soot combustion rates between $425^{\circ} \mathrm{C}$ and $450^{\circ} \mathrm{C}$. In addition, the copper-doped catalyst conveniently accelerates the $\mathrm{NO}$ oxidation to $\mathrm{NO}_{2}$ at low-medium temperatures, and interestingly, it showed slightly higher activity at $450^{\circ} \mathrm{C}$ than the platinum-based catalyst for soot combustion. As far as the authors concern, this is the first time that a ceria-based (noble metal-free) catalyst has been reported to be more active for soot combustion than a platinum-based one under selected simulated diesel exhaust conditions.

On the other hand, it can be confirmed from the experimental results that the high activity of the platinum-based catalyst is mostly related to a $\mathrm{NO}_{2}$-assisted soot combustion mechanism, since this catalyst presents also a great $\mathrm{NO} \leftrightarrow \mathrm{NO}_{2}$ recycling efficiency.

Finally, the kinetic data obtained from this study have been proved to be in accordance with the literature data. Global activation energies followed the trend: Pt/alumina $<2 \% \mathrm{CuO} /$ ceria-zirconia < Ceria-zirconia. In general, this trend was very similar to that found for the catalytic activity. All the catalysts decrease the activation energy with regard to the uncatalysed reaction, except for the $\mathrm{NO}_{2} / \mathrm{O}_{2}$-soot reaction, which is very similar to that found for the catalysed reaction with platinum under $\mathrm{NOx} / \mathrm{O}_{2}$, providing additional evidences about the relevance of the $\mathrm{NO}_{2}$-assisted soot combustion for the Pt catalyst. 


\section{Acknowledgements}

The authors gratefully acknowledge the financial support of Generalitat Valenciana (PROMETEOII/2014/010 project) and the Spanish Ministry of Economy and Competitiveness (CTQ2012-30703 project) and the UE (FEDER funding).

\section{References}

[1] J.P.A. Neeft, M. Makkee, J.A. Moulijn, Diesel particulate emission control, Fuel Processing Technology 47 (1996) 1-69.

[2] B.R. Stanmore, J.F. Brilhac, P. Gilot, The oxidation of soot: a review of experiments, mechanisms and models, Carbon 39 (2001) 2247-2268.

[3] M.V. Twigg, Progress and future challenges in controlling automotive exhaust gas emissions, Applied Catalysis B: Environmental 70 (2007) 2-15.

[4] B.A.A.L. van Setten, J.M. Schouten, M. Makkee, J.A. Moulijn, Realistic contact for soot with an oxidation catalyst for laboratory studies, Applied Catalysis B: Environmental 28 (2000) 253-257.

[5] B.A.A.L. van Setten, M. Makkee, J.A. Moulijn, Science and technology of catalytic diesel particulate filters, Catalysis Reviews Science and Engineering 43 (2001) 489-564.

[6] K. Choi, N.W. Cant, D.L. Trimm, Gasification of carbonaceous particulates, Journal of Chemical Technology and Biotechnology 71 (1998) 57-60.

[7] P.G. Gray, D.D. Do, Modelling of the interaction of nitrogen dioxide with activated carbon ii. Kinetics of reaction with pore evolution, Chemical Engineering Communications 125 (1993) 109-120.

[8] H. Muckenhuber, H. Grothe, A DRIFTS study of the heterogeneous reaction of $\mathrm{NO}_{2}$ with carbonaceous materials at elevated temperature, Carbon 45 (2007) 321329.

[9] $\mathrm{H}$. Muckenhuber, $\mathrm{H}$. Grothe, The heterogeneous reaction between soot and $\mathrm{NO}_{2}$ at elevated temperature, Carbon 44 (2006) 546-559.

[10] F. Jacquot, V. Logie, J.F. Brilhac, P. Gilot, Kinetics of the oxidation of carbon black by $\mathrm{NO}_{2}$ : Influence of the presence of water and oxygen, Carbon 40 (2002) 335-343.

[11] M. Jeguirim, V. Tschamber, J.F. Brilhac, Kinetics of catalyzed and non-catalyzed soot oxidation with nitrogen dioxide under regeneration particle trap conditions, Journal of Chemical Technology and Biotechnology 84 (2009) 770-776.

[12] M. Jeguirim, V. Tschamber, J.F. Brilhac, P. Ehrburger, Oxidation mechanism of carbon black by $\mathrm{NO}_{2}$ : Effect of water vapour, Fuel 84 (2005) 1949-1956. 
[13] M. Jeguirim, V. Tschamber, J.F. Brilhac, P. Ehrburger, Interaction mechanism of $\mathrm{NO}_{2}$ with carbon black: effect of surface oxygen complexes, Journal of Analytical and Applied Pyrolysis 72 (2004) 171-181.

[14] B.A.A.L. van Setten, R. van Dijk, S.J. Jelles, M. Makkee, J.A. Moulijn, The potential of supported molten salts in the removal of soot from diesel exhaust gas, Applied Catalysis B: Environmental 21 (1999) 51-61.

[15] A. Setiabudi, B.A.A.L. van Setten, M. Makkee, J.A. Moulijn, The influence of NOx on soot oxidation rate: molten salt versus platinum, Applied Catalysis B: Environmental 35 (2002) 159-166.

[16] A. Setiabudi, N.K. Allaart, M. Makkee, J.A. Moulijn, In situ visible microscopic study of molten $\mathrm{Cs}_{2} \mathrm{SO}_{4} \cdot \mathrm{V}_{2} \mathrm{O}_{5}$-soot system: Physical interaction, oxidation rate, and data evaluation, Applied Catalysis B: Environmental 60 (2005) 233-243.

[17] B.A.A.L. van Setten, Development of a liquid catalyst for diesel soot oxidation; From powder to prototype, PhD thesis (2001) Delft.

[18] B. Azambre, S. Collura, P. Darcy, J.M. Trichard, P. da Costa, A. García-García, A. Bueno-López, Effects of a Pt/Ce $e_{0.68} \mathrm{Zr}_{0.32} \mathrm{O}_{2}$ catalyst and $\mathrm{NO}_{2}$ on the kinetics of diesel soot oxidation from thermogravimetric analyses, Fuel Processing Technology 92 (2011) 363-371.

[19] P. Darcy, P. Da Costa, H. Mellottée, J.M. Trichard, G. Djéga-Mariadassou, Kinetics of catalyzed and non-catalyzed oxidation of soot from a diesel engine, Catalysis Today 119 (2007) 252-256.

[20] B. Dernaika, D. Uner, A simplified approach to determine the activation energies of uncatalyzed and catalyzed combustion of soot, Applied Catalysis B: Environmental 40 (2003) 219-229.

[21] M. Jeguirim, V. Tschamber, P. Ehrburger, Catalytic effect of platinum on the kinetics of carbon oxidation by $\mathrm{NO}_{2}$ and $\mathrm{O}_{2}$, Applied Catalysis B: Environmental 76 (2007) 235-240.

[22] E. Aneggi, C. de Leitenburg, A. Trovarelli, On the role of lattice/surface oxygen in ceria-zirconia catalysts for diesel soot combustion, Catalysis Today 181 (2012) 108-115.

[23] M.S. Gross, M.A. Ulla, C.A. Querini, Diesel particulate matter combustion with $\mathrm{CeO}_{2}$ as catalyst. Part I: System characterization and reaction mechanism, Journal of Molecular Catalysis A: Chemical 352 (2012) 86-94.

[24] Q. Liang, X. Wu, D. Weng, Z. Lu, Selective oxidation of soot over Cu doped ceria/ceria-zirconia catalysts, Catalysis Communications 9 (2008) 202-206.

[25] C.F. Oliveira, F.A.C. Garcia, D.R. Araújo, J.L. Macedo, S.C.L. Dias, J.A. Dias, Effects of preparation and structure of cerium-zirconium mixed oxides on diesel soot catalytic combustion, Applied Catalysis A: General 413-414 (2012) 292-300. 
[26] X. Wu, Q. Liang, D. Weng, Z. Lu, The catalytic activity of $\mathrm{CuO}^{-\mathrm{CeO}_{2} \text { mixed }}$ oxides for diesel soot oxidation with a $\mathrm{NO} / \mathrm{O}_{2}$ mixture, Catalysis Communications 8 (2007) 2110-2114.

[27] L. Zhu, J. Yu, X. Wang, Oxidation treatment of diesel soot particulate on $\mathrm{Ce}_{\mathrm{x}} \mathrm{Zr}_{1}$ ${ }_{x} \mathrm{O}_{2}$, Journal of Hazardous Materials 140 (2007) 205-210.

[28] N. Zouaoui, M. Issa, D. Kehrli, M. Jeguirim, $\mathrm{CeO}_{2}$ catalytic activity for soot oxidation under $\mathrm{NO} / \mathrm{O}_{2}$ in loose and tight contact, Catalysis Today 189 (2012) 6569.

[29] S. Wagloehner, S. Kureti, Modelling of the kinetics of the catalytic soot oxidation on $\mathrm{Fe}_{2} \mathrm{O}_{3}$, Applied Catalysis B: Environmental 129 (2013) 501-508.

[30] E. Aneggi, C. de Leitenburg, G. Dolcetti, A. Trovarelli, Promotional effect of rare earths and transition metals in the combustion of diesel soot over $\mathrm{CeO}_{2}$ and $\mathrm{CeO}_{2}$ $\mathrm{ZrO}_{2}$, Catalysis Today 114 (2006) 40-47.

[31] D. Reichert, T. Finke, N. Atanassova, H. Bockhorn, S. Kureti, Global kinetic modelling of the reaction of soot with $\mathrm{O}_{2}$ and $\mathrm{NOx}$ on $\mathrm{Fe}_{2} \mathrm{O}_{3}$ catalyst, Applied Catalysis B: Environmental 84 (2008) 803-812.

[32] K.i. Shimizu, H. Kawachi, A. Satsuma, Study of active sites and mechanism for soot oxidation by silver-loaded ceria catalyst, Applied Catalysis B: Environmental 96 (2010) 169-175.

[33] F. Bin, C. Song, G. Lv, J. Song, K. Wang, X. Li, Soot low-temperature combustion on $\mathrm{Cu}-\mathrm{Zr} / \mathrm{ZSM}-5$ catalysts in $\mathrm{O}_{2} / \mathrm{He}$ and $\mathrm{NO} / \mathrm{O}_{2} / \mathrm{He}$ atmospheres, Proceedings of the Combustion Institute 34 (2013) 2303-2311.

[34] J.P.A. Neeft, M. Makkee, J.A. Moulijn, Catalytic oxidation of carbon black - I. Activity of catalysts and classification of oxidation profiles, Fuel 77 (1998) 111119.

[35] I. Atribak, I. Bueno-López, A. García-García, Combined removal of diesel soot particulates and $\mathrm{NOx}$ over $\mathrm{CeO}_{2}-\mathrm{ZrO}_{2}$ mixed oxides, Journal of Catalysis 259 (2008) 123-132.

[36] J. Giménez-Mañogil, A. Bueno-López, A. García-García, Preparation, characterisation and testing of $\mathrm{CuO} / \mathrm{Ce}_{0.8} \mathrm{Zr}_{0.2} \mathrm{O}_{2}$ catalysts for $\mathrm{NO}$ oxidation to $\mathrm{NO}_{2}$ and mild temperature diesel soot combustion, Applied Catalysis B: Environmental 152-153 (2014) 99-107.

[37] M.S. Gross, M.A. Ulla, C.A. Querini, Catalytic oxidation of diesel soot: New characterization and kinetic evidence related to the reaction mechanism on $\mathrm{K} / \mathrm{CeO}_{2}$ catalyst, Applied Catalysis A: General 360 (2009) 81-88.

[38] A. Setiabudi, M. Makkee, J.A. Moulijn, An optimal NOx assisted abatement of diesel soot in an advanced catalytic filter design, Applied Catalysis B: Environmental 42 (2003) 35-45. 
[39] A. Setiabudi, J. Chen, G. Mul, M. Makkee, J.A. Moulijn, $\mathrm{CeO}_{2}$ catalysed soot oxidation: The role of active oxygen to accelerate the oxidation conversion, Applied Catalysis B: Environmental 51 (2004) 9-19.

[40] K.O. Lee, H. Seong, S.M. Choi, Detailed analysis of kinetic reactions in soot oxidation by simulated diesel exhaust emissions, Proceedings of the Combustion Institute 34 (2013) 3057-3065.

[41] J.P.A. Neeft, M. Makkee, J.A. Moulijn, Metal oxides as catalysts for the oxidation of soot, Chemical Engineering Journal 64 (1996) 295-302.

[42] R.J. Madon, M. Boudart, Experimental criterion for the absence of artifacts in the measurement of rates of heterogeneous catalytic reactions, Industrial and Engineering Chemistry Fundamentals 21 (1982) 438-447.

[43] M.A. Peralta, M.A. Ulla, C.A. Querini, Diesel soot and NOx abatement: $\mathrm{K} / \mathrm{La}_{2} \mathrm{O}_{3}$ catalyst stability, Applied Catalysis B: Environmental 101 (2010) 38-44.

[44] I. Atribak, F.E. López-Suárez, A. Bueno-López, A. García-García, New insights into the performance of ceria-zirconia mixed oxides as soot combustion catalysts. Identification of the role of "active oxygen" production, Catalysis Today 176 (2011) 404-408.

[45] N. Guillén-Hurtado, F.E. López-Suárez, A. Bueno-López, A. García-García, Behavior of different soot combustion catalysts under $\mathrm{NOx} / \mathrm{O}_{2}$. Importance of the catalyst-soot contact, Reaction Kinetics, Mechanisms, and Catalysis 111 (2014) 167-182.

[46] N. Zouaoui, M. Labaki, M. Jeguirim, Diesel soot oxidation by nitrogen dioxide, oxygen and water under engine exhaust conditions: Kinetics data related to the reaction mechanism, Comptes Rendus Chimie 17 (2014) 672-680.

[47] I. Atribak, B. Azambre, A. Bueno-López, A. García-García, Effect of $\mathrm{NO}_{\mathrm{x}}$ adsorption/desorption over ceria-zirconia catalysts on the catalytic combustion of model soot, Applied Catalysis B: Environmental 92 (2009) 126-137.

[48] A. Yezerets, N.W. Currier, D.H. Kim, H.A. Eadler, W.S. Epling, C.H.F. Peden, Differential kinetic analysis of diesel particulate matter (soot) oxidation by oxygen using a step-response technique, Applied Catalysis B: Environmental 61 (2005) 120-129.

[49] M. Kalogirou, Z. Samaras, Soot oxidation kinetics from TG experiments, Journal of Thermal Analysis and Calorimetry 99 (2010) 1005-1010.

[50] I.P. Kandylas, O.A. Haralampous, G.C. Koltsakis, Diesel Soot Oxidation with $\mathrm{NO}_{2}$ : Engine Experiments and Simulations, Industrial and Engineering Chemistry Research 41 (2002) 5372-5384. 


\section{LIST OF TABLES}

Table 1. Summary of the experimental conditions to study mass transfer phenomena.

\begin{tabular}{ccccccc}
\hline Experiments & $\begin{array}{c}\text { Catalyst } \\
(\mathbf{m g})\end{array}$ & SiC $(\mathbf{m g})$ & Soot $(\mathbf{m g})$ & $\begin{array}{c}\text { Gas flow } \\
(\mathbf{m l} / \mathbf{m i n})\end{array}$ & NOx (ppm) & $\mathbf{O}_{\mathbf{2}}(\%)$ \\
\hline A1 & 80 & 300 & 20 & 500 & 500 & 5 \\
A2 & 50 & 188 & 12 & 312 & 500 & 5 \\
A3 & 40 & 150 & 10 & 250 & 500 & 5 \\
B1 & 60 & 300 & 20 & 500 & 500 & 5 \\
\hline
\end{tabular}

Table 2. Activity and kinetic data obtained from TPR soot combustion (under different atmospheres).

\begin{tabular}{cccccc}
\hline $\begin{array}{c}\text { Catalyst } \\
\text { (Atmosphere) }\end{array}$ & $\begin{array}{c}\text { Selec. } \\
\mathbf{C O}_{\mathbf{2}}(\%)\end{array}$ & $\begin{array}{c}\mathbf{T}_{\text {onset }}{ }^{\mathbf{a}} \\
\left({ }^{\circ} \mathrm{C}\right)\end{array}$ & $\mathbf{T}_{\mathbf{5}}{ }^{\mathbf{b}}\left({ }^{\circ} \mathbf{C}\right)$ & $\mathbf{T}_{\mathbf{5 0}}{ }^{\mathbf{b}}\left({ }^{\circ} \mathbf{C}\right)$ & $\mathbf{E}_{\mathbf{a}}{ }^{\mathbf{c}}(\mathbf{k J / m o l})$ \\
\hline $\mathrm{CZ}\left(\mathrm{NOx} / \mathrm{O}_{2}\right)$ & 85 & 281 & 400 & 513 & 84 \\
$\mathrm{Cu} 2 / \mathrm{CZ}\left(\mathrm{NOx} / \mathrm{O}_{2}\right)$ & 96 & 238 & 377 & 518 & 62 \\
$\mathrm{Pt} 1 / \mathrm{AL}\left(\mathrm{NOx} / \mathrm{O}_{2}\right)$ & 100 & 159 & 330 & 474 & 56 \\
$\mathrm{NC}\left(\mathrm{NOx} / \mathrm{O}_{2}\right)$ & 35 & 387 & 502 & 606 & 111 \\
$\mathrm{NC}\left(\mathrm{NO}_{2} / \mathrm{O}_{2}\right)$ & 60 & 247 & 406 & 588 & 43 \\
$\mathrm{NC}\left(\mathrm{O}_{2}\right)$ & 40 & 363 & 496 & 592 & 124 \\
$\mathrm{CZ}\left(\mathrm{O}_{2}\right)$ & 97 & 347 & 475 & 566 & 124 \\
$\mathrm{Cu} 2 / \mathrm{CZ}\left(\mathrm{O}_{2}\right)$ & 100 & 330 & 472 & 562 & 125 \\
$\mathrm{Pt} 1 / \mathrm{AL}\left(\mathrm{O}_{2}\right)$ & 100 & 317 & 475 & 585 & 100 \\
\hline
\end{tabular}

\footnotetext{
${ }^{\mathrm{a}} \mathrm{T}_{\text {onset }}$ is the temperature required to initiate the soot combustion.

${ }^{\mathrm{b}} \mathrm{T}_{5}$ and $\mathrm{T}_{50}$ are the temperatures required to convert $5 \%$ and $50 \%$ of the soot, respectively.

${ }^{\mathrm{c}}$ Global activation energy, calculated considering differential reactor model at very low conversion levels.
} 
Table 3. Global activation energies calculated from isothermal soot combustion experiments (at $400^{\circ} \mathrm{C}, 425^{\circ} \mathrm{C}$ and $450^{\circ} \mathrm{C}$ ).

\begin{tabular}{ccccccc}
\hline \multirow{2}{*}{ Catalyst } & \multicolumn{6}{c}{$\mathbf{E}_{\mathbf{a}}(\mathbf{k J / m o l}) \mathbf{a t}$ 'x\%' conversion } \\
\cline { 2 - 7 } & $\mathbf{5}$ & $\mathbf{1 0}$ & $\mathbf{2 0}$ & $\mathbf{3 0}$ & $\mathbf{4 0}$ & $\mathbf{5 0}$ \\
\hline $\mathrm{CZ}$ & 87 & 78 & 80 & 81 & 85 & 95 \\
Cu2/CZ & 63 & 66 & 66 & 69 & 69 & 64 \\
Pt1/AL & 42 & 45 & 46 & 47 & 48 & 48 \\
\hline
\end{tabular}

Table 4. Activation energies for catalysed soot combustion reaction (both in loose and tight contact modes) reported in the literature.

\begin{tabular}{|c|c|c|c|c|c|c|}
\hline Sample & Catalyst & Contact & Gases & Method $^{\mathrm{a}}$ & $\begin{array}{c}E_{a} \\
(\mathrm{~kJ} / \mathrm{mol})\end{array}$ & Ref \\
\hline Vulcan & $\mathrm{CeO}_{2}$ & Tight & $10 \% \mathrm{O}_{2}$ & FBR & 44 & [28] \\
\hline Vulcan & $\mathrm{CeO}_{2}$ & Tight & $500 p p m N O+10 \% O_{2}$ & FBR & 59 & [28] \\
\hline Vulcan & $\mathrm{CeO}_{2}$ & Loose & $10 \% \mathrm{O}_{2}$ & FBR & 135 & [28] \\
\hline $\begin{array}{l}\text { Vulcan } \\
\text { Diesel }\end{array}$ & $\mathrm{CeO}_{2}$ & Loose & $500 p p m N O+10 \% \mathrm{O}_{2}$ & FBR & 72 & [28] \\
\hline $\begin{array}{l}\text { soot } \\
\text { Diesel }\end{array}$ & $\mathrm{Ce}-\mathrm{Zr}$ & Loose & $20 \% \mathrm{O}_{2}$ & TG & 138 & [18] \\
\hline soot & $\mathrm{Ce}-\mathrm{Zr}$ & Loose & $700 p_{p m N O}+10 \% O_{2}$ & TG & 77 & [18] \\
\hline Printex-U & $\mathrm{Ce}-\mathrm{Zr}$ & Loose & $10 \% \mathrm{O}_{2}$ & FBR & 149 & [27] \\
\hline Printex-U & $\mathrm{Cs}_{2} \mathrm{SO}_{4} \cdot \mathrm{V}_{2} \mathrm{O}_{5}$ & Loose & $10 \% \mathrm{O}_{2}$ & FBR & 166 & [17] \\
\hline $\begin{array}{c}\text { Printex-U } \\
\text { Diesel }\end{array}$ & $\mathrm{Cs}_{2} \mathrm{SO}_{4} \cdot \mathrm{V}_{2} \mathrm{O}_{5}$ & Loose & $20 \% \mathrm{O}_{2}$ & TG & 88.4 & [16] \\
\hline $\begin{array}{c}\text { soot } \\
\text { Diesel }\end{array}$ & $\mathrm{Pt} / \mathrm{Al}_{2} \mathrm{O}_{3}$ & Loose & $20 \% \mathrm{O}_{2}$ & TG & 139 & [18] \\
\hline $\begin{array}{c}\text { soot } \\
\text { Diesel }\end{array}$ & $\mathrm{Pt} / \mathrm{Al}_{2} \mathrm{O}_{3}$ & Loose & $700 p_{p m N O}+10 \% O_{2}$ & TG & 107 & [18] \\
\hline soot & $\mathrm{Pt} / \mathrm{Al}_{2} \mathrm{O}_{3}$ & Loose & $20 \% \mathrm{O}_{2}$ & FBR & 168 & [20] \\
\hline
\end{tabular}




\section{LIST OF FIGURES}

Figure 1. Soot combustion rates versus soot conversion in isothermal conditions $\left(450^{\circ} \mathrm{C}\right)$ with similar space velocity.

Figure 2. Soot combustion rates versus soot conversion in isothermal conditions $\left(450^{\circ} \mathrm{C}\right)$ with different catalyst masses.

Figure 3. Soot conversion curves versus temperature for catalysed reactions under $\mathrm{NOx} / \mathrm{O}_{2}$ and non-catalysed (NC) reactions under $\mathrm{NOx} / \mathrm{O}_{2}$ and $\mathrm{NO}_{2} / \mathrm{O}_{2}$.

Figure 4. Soot conversion curves versus temperature for catalysed and noncatalysed (NC) reactions under $\mathrm{O}_{2}$.

Figure 5. $\mathrm{NO}_{2}$ production profiles during blank TPR experiments for the catalysts.

Figure 6. $\mathrm{NO}_{2}$ slip production, in $\mathrm{TPR}$ soot combustion experiments, under $\mathrm{NOx} / \mathrm{O}_{2}$.

Figure 7. Soot combustion rates versus soot conversion in isothermal conditions at different temperatures: a) $400^{\circ} \mathrm{C}$, b) $425^{\circ} \mathrm{C}$ and c) $450^{\circ} \mathrm{C}$. (Dotted line corresponds to a reproducibility experiment for Pt1/AL sample).

Figure 8. Soot combustion rates versus soot conversion in isothermal conditions for each catalyst: a) CZ, b) Cu2/CZ and c) Pt1/AL.

Figure 9. $\mathrm{NO}_{2}$ slip production, in isothermal soot combustion experiments, under $\mathrm{NOx} / \mathrm{O}_{2}$.

Figure 10. Arrhenius plots for the catalysts at $20 \%$ of soot conversion. 


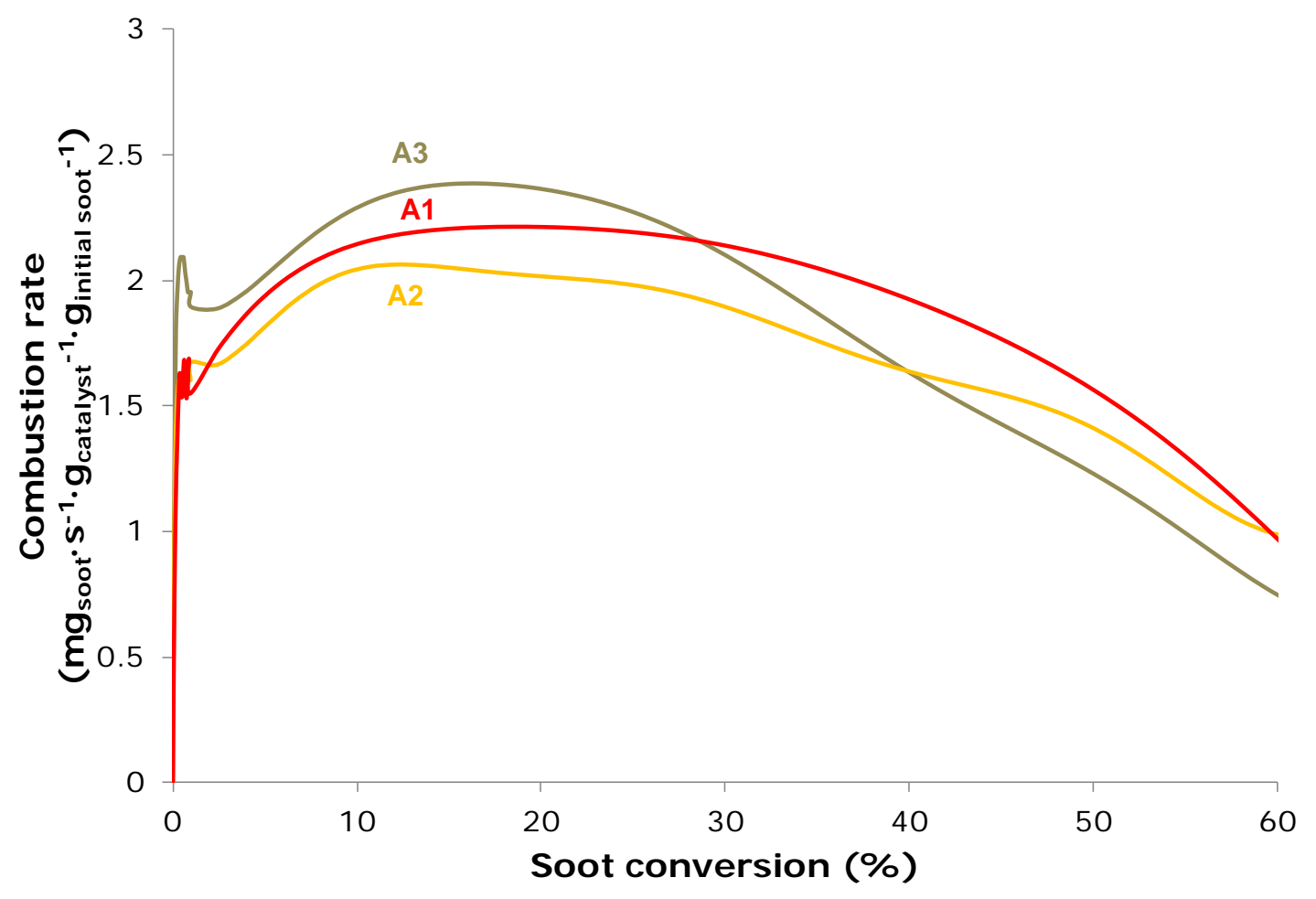

Figure 1. 


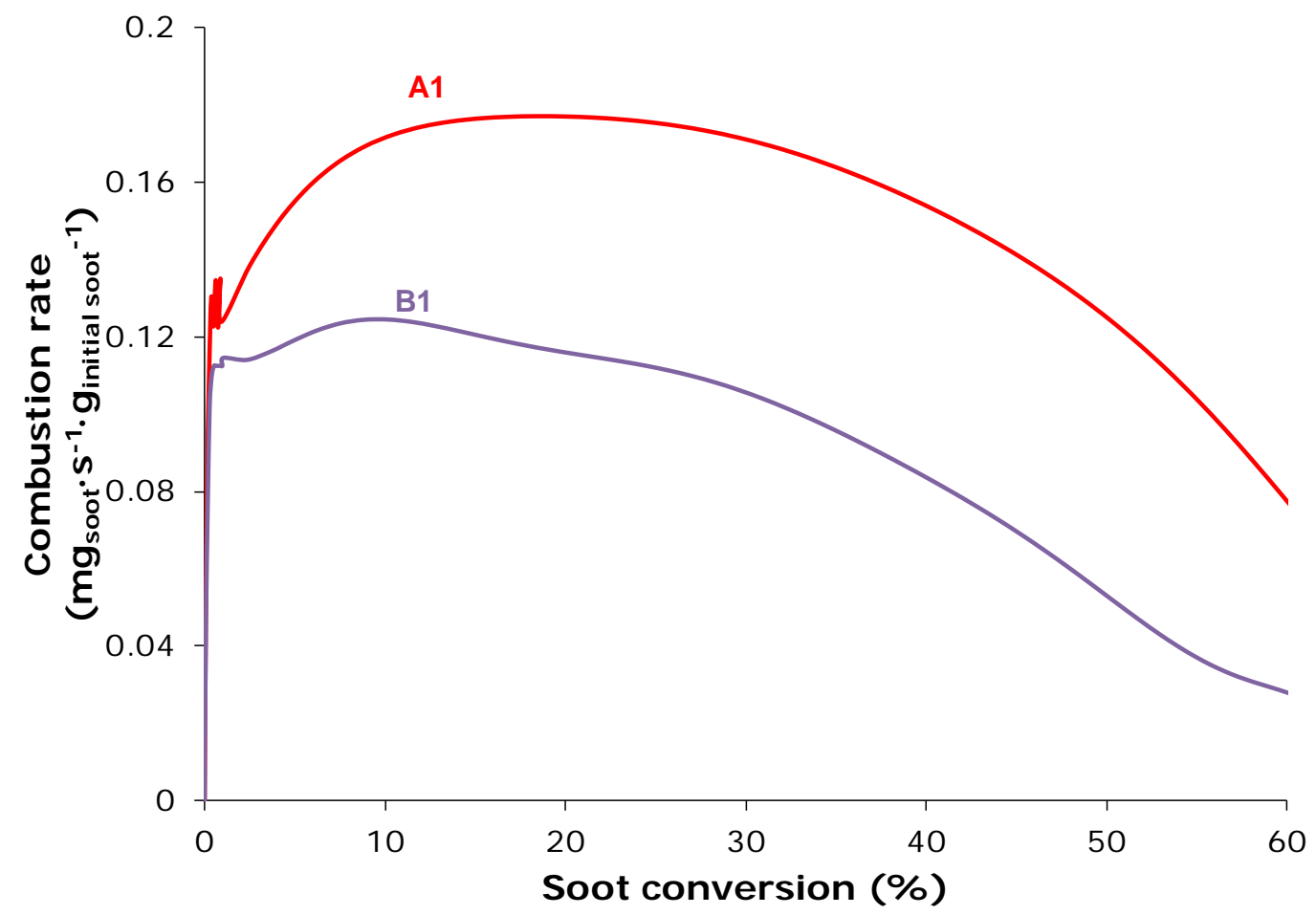

Figure 2. 


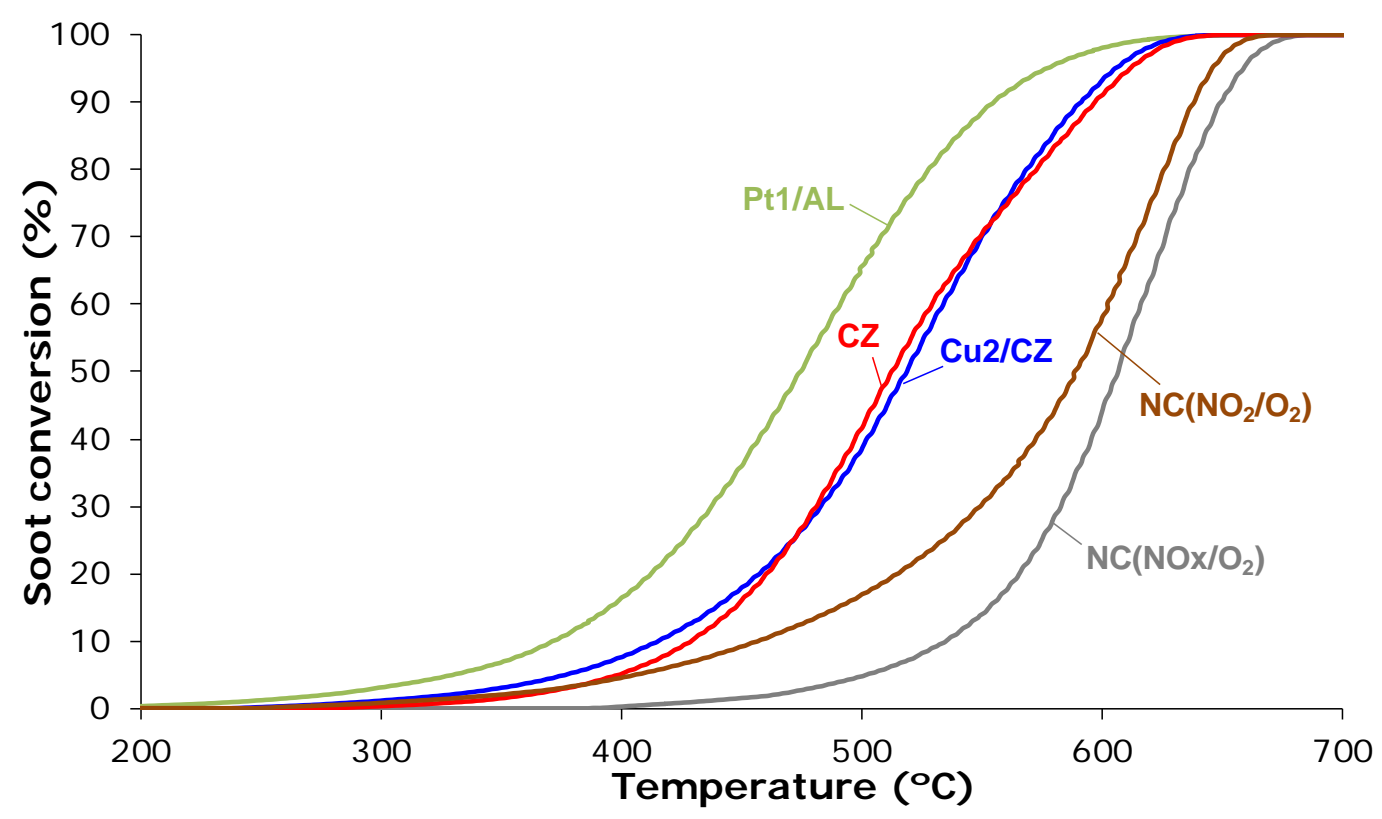

Figure 3. 


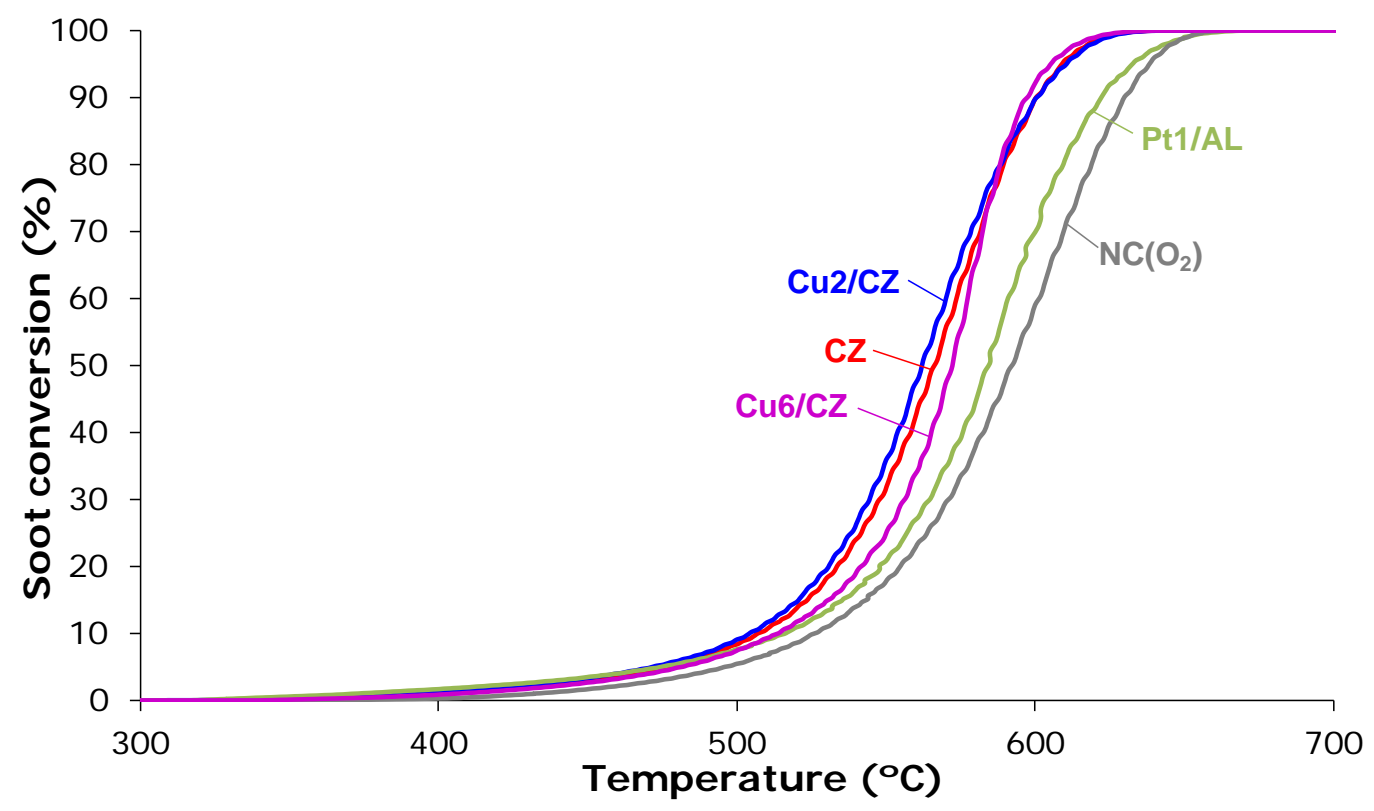

Figure 4. 


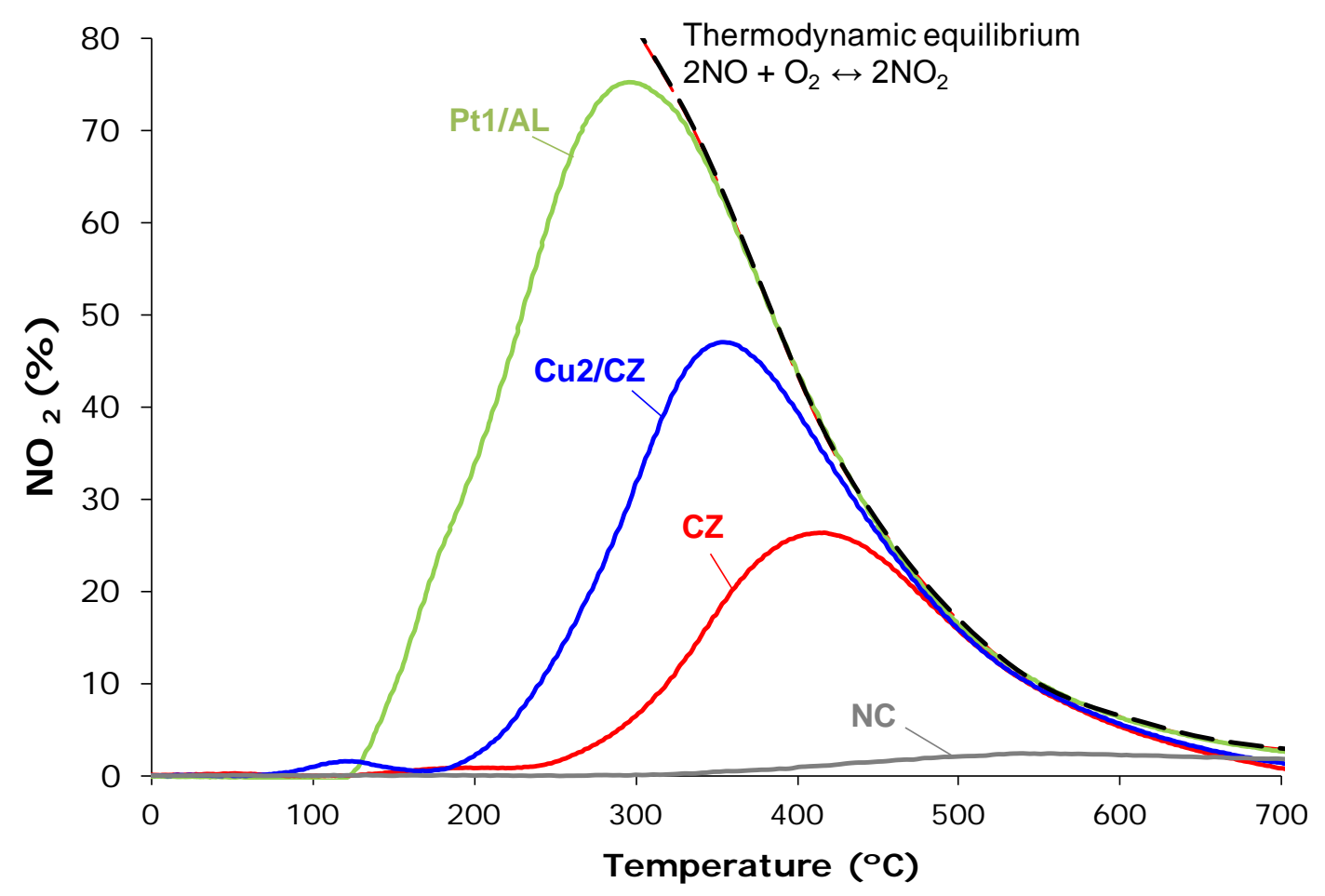

Figure 5. 


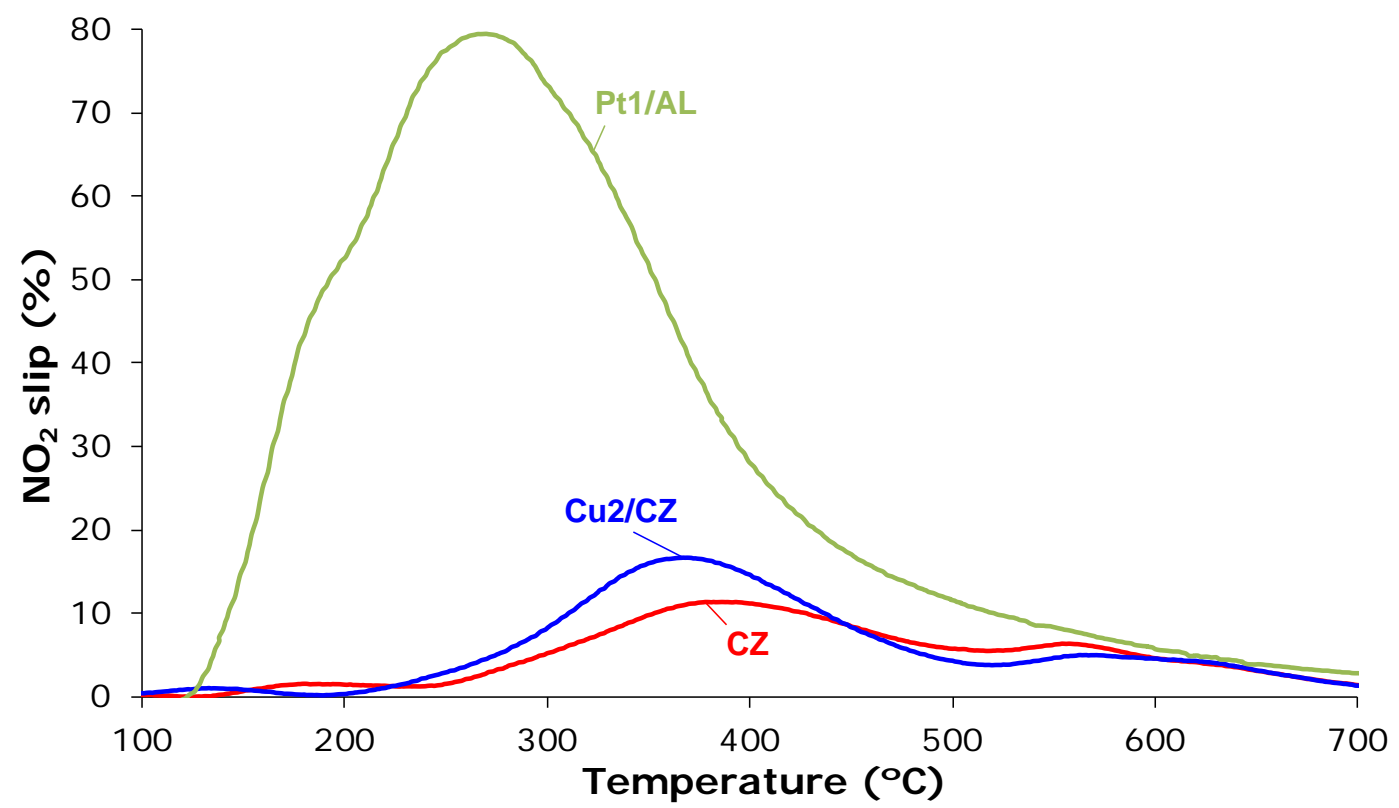

Figure 6. 

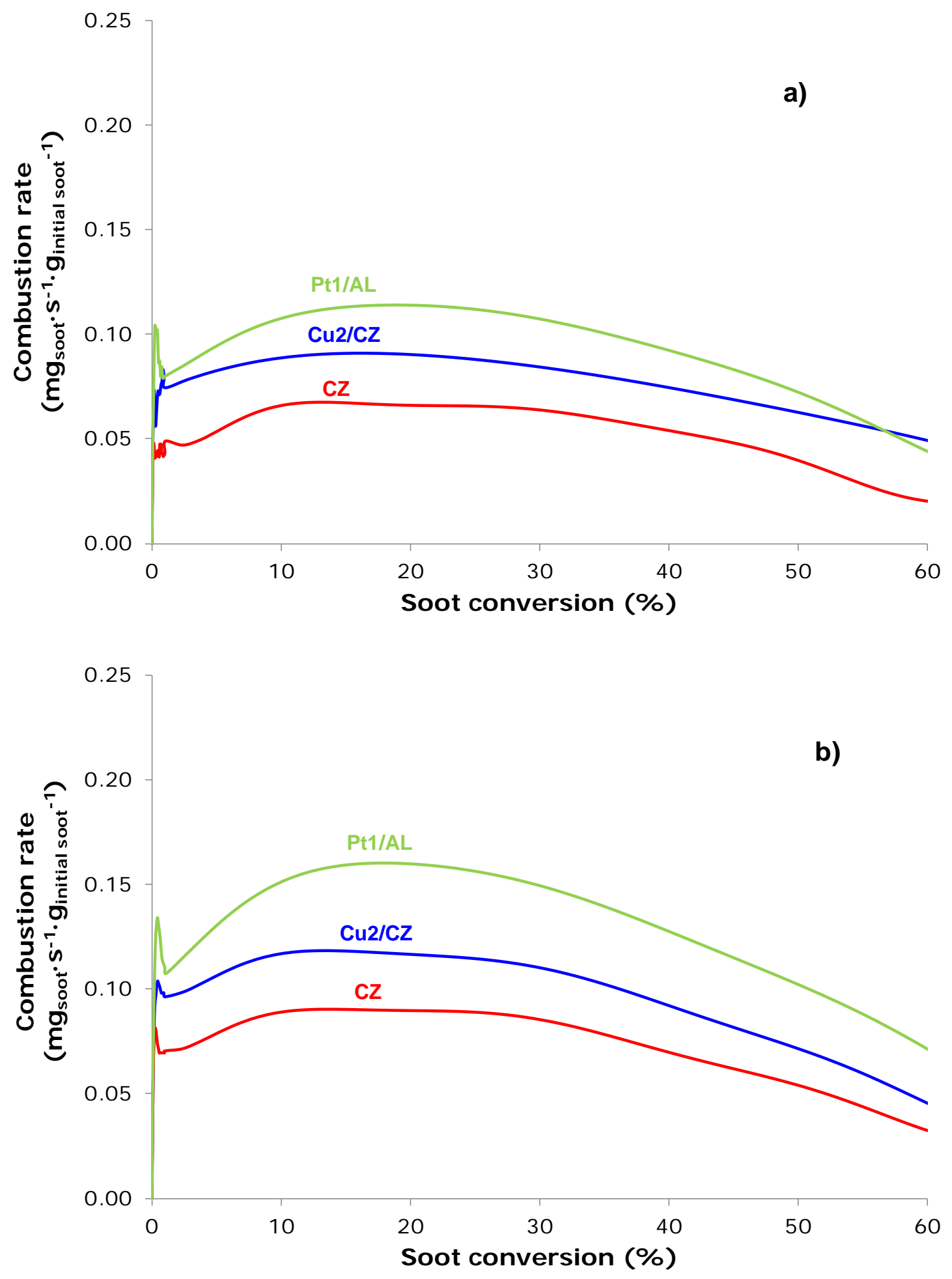

Figure 7. 


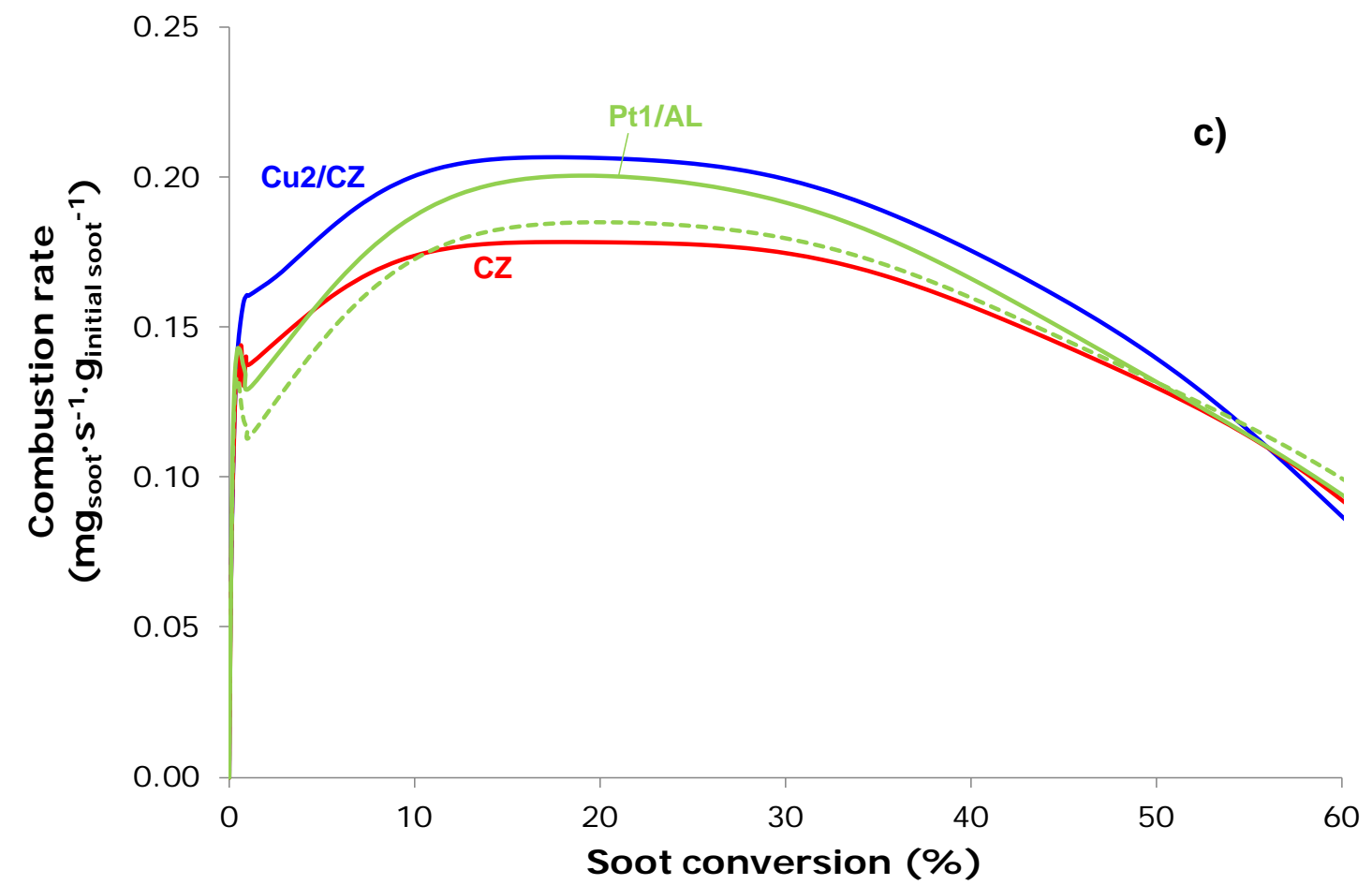

Figure 7. 

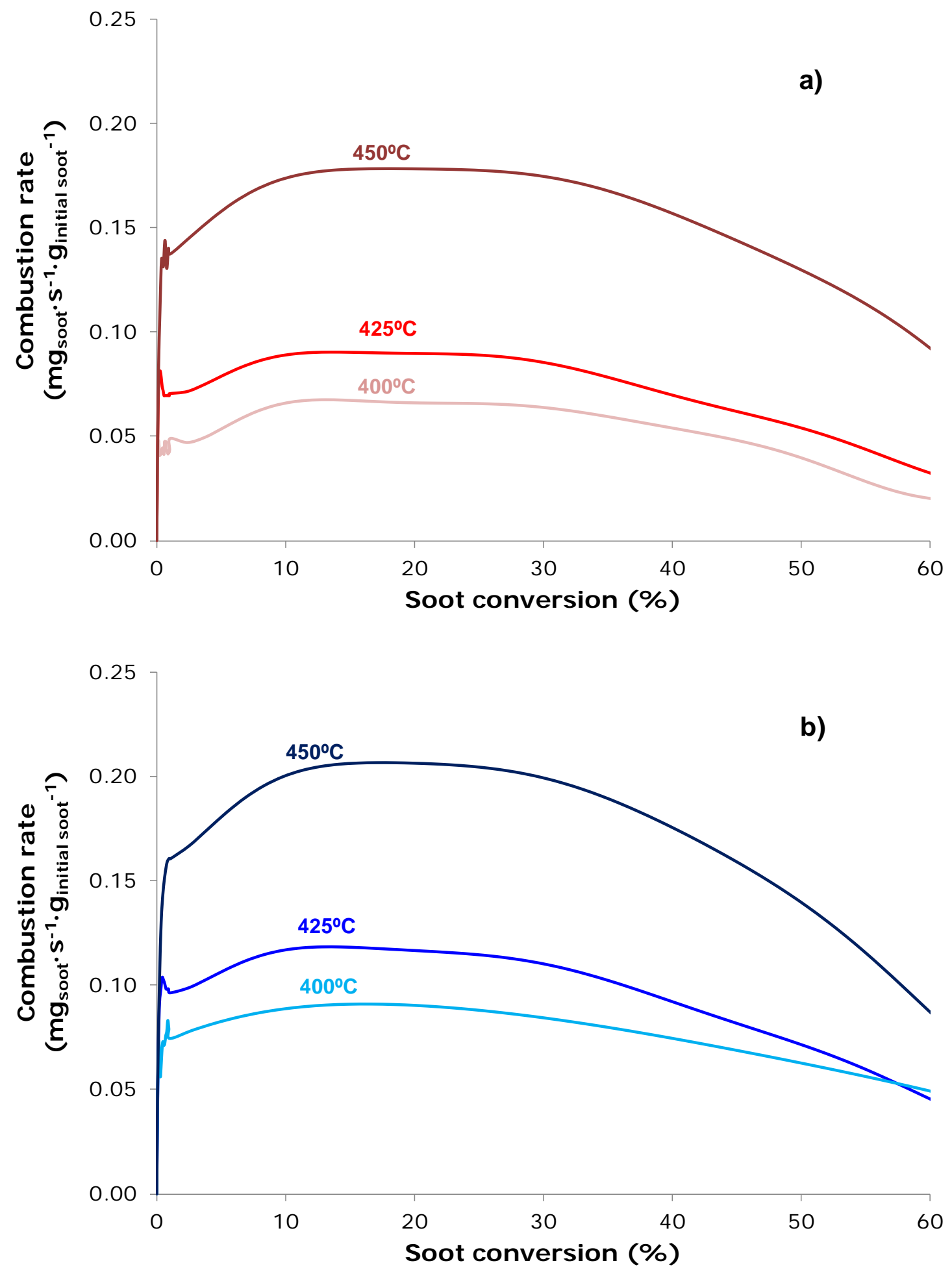

Figure 8. 


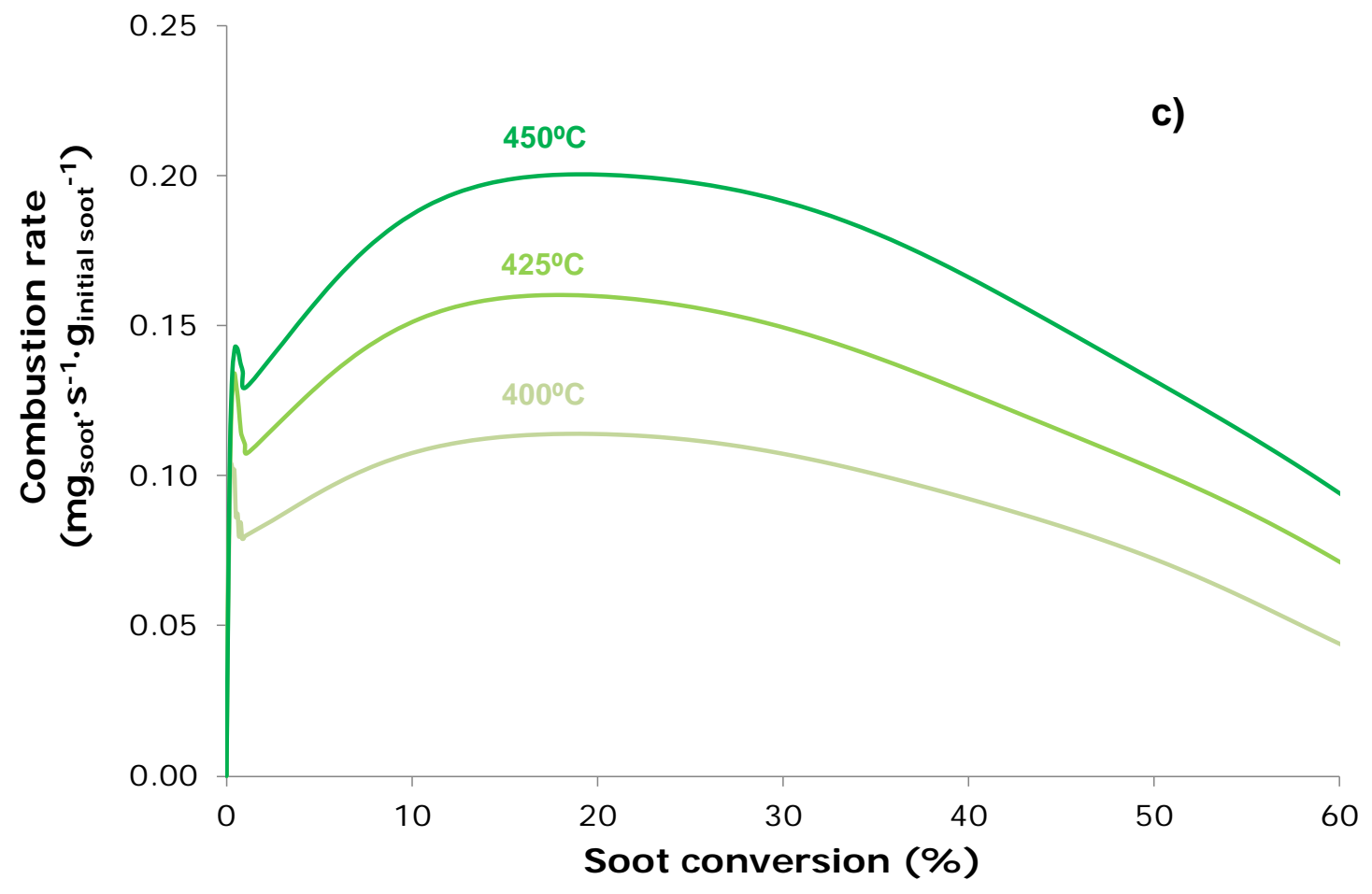

Figure 8. 


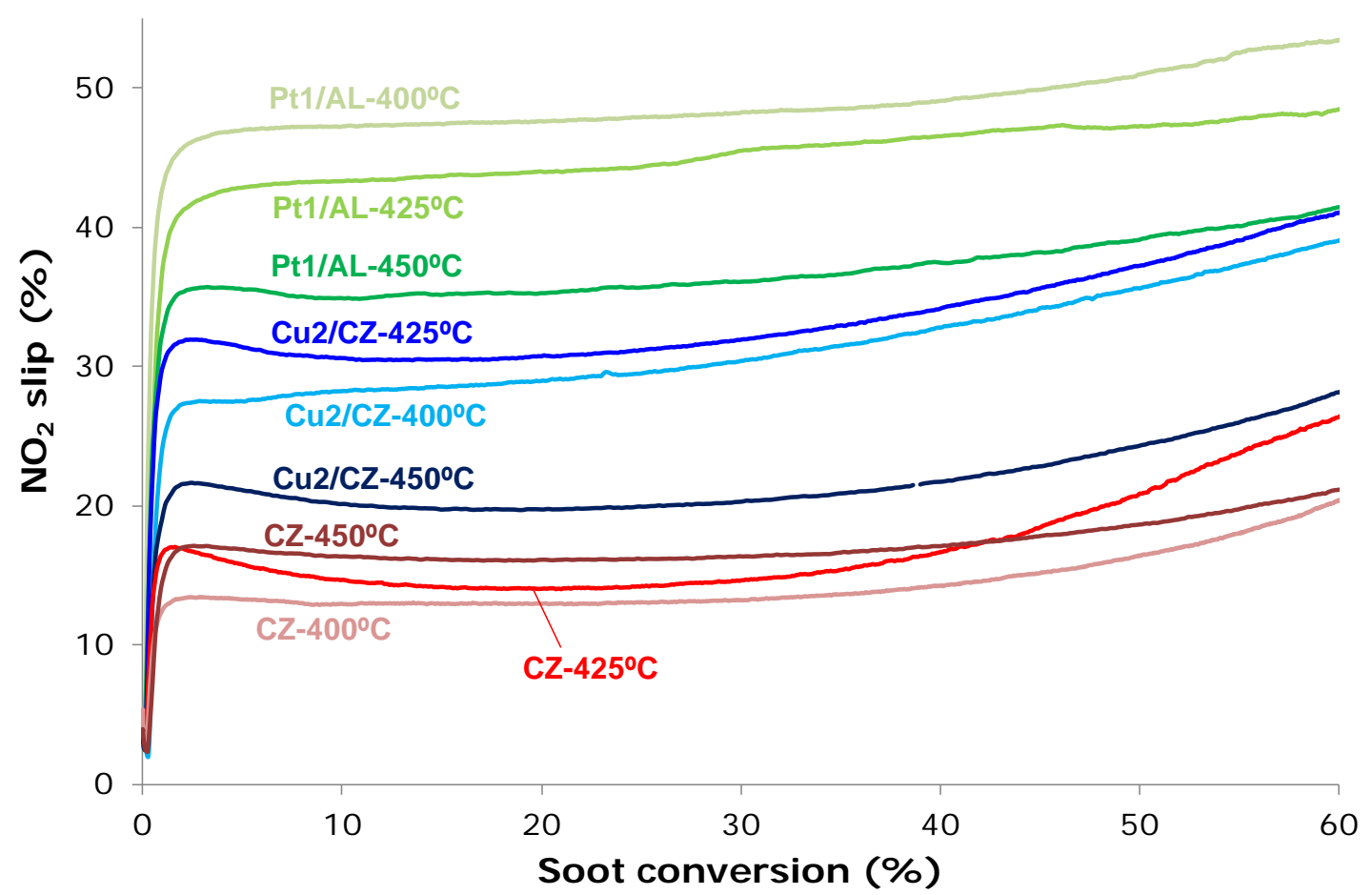

Figure 9. 


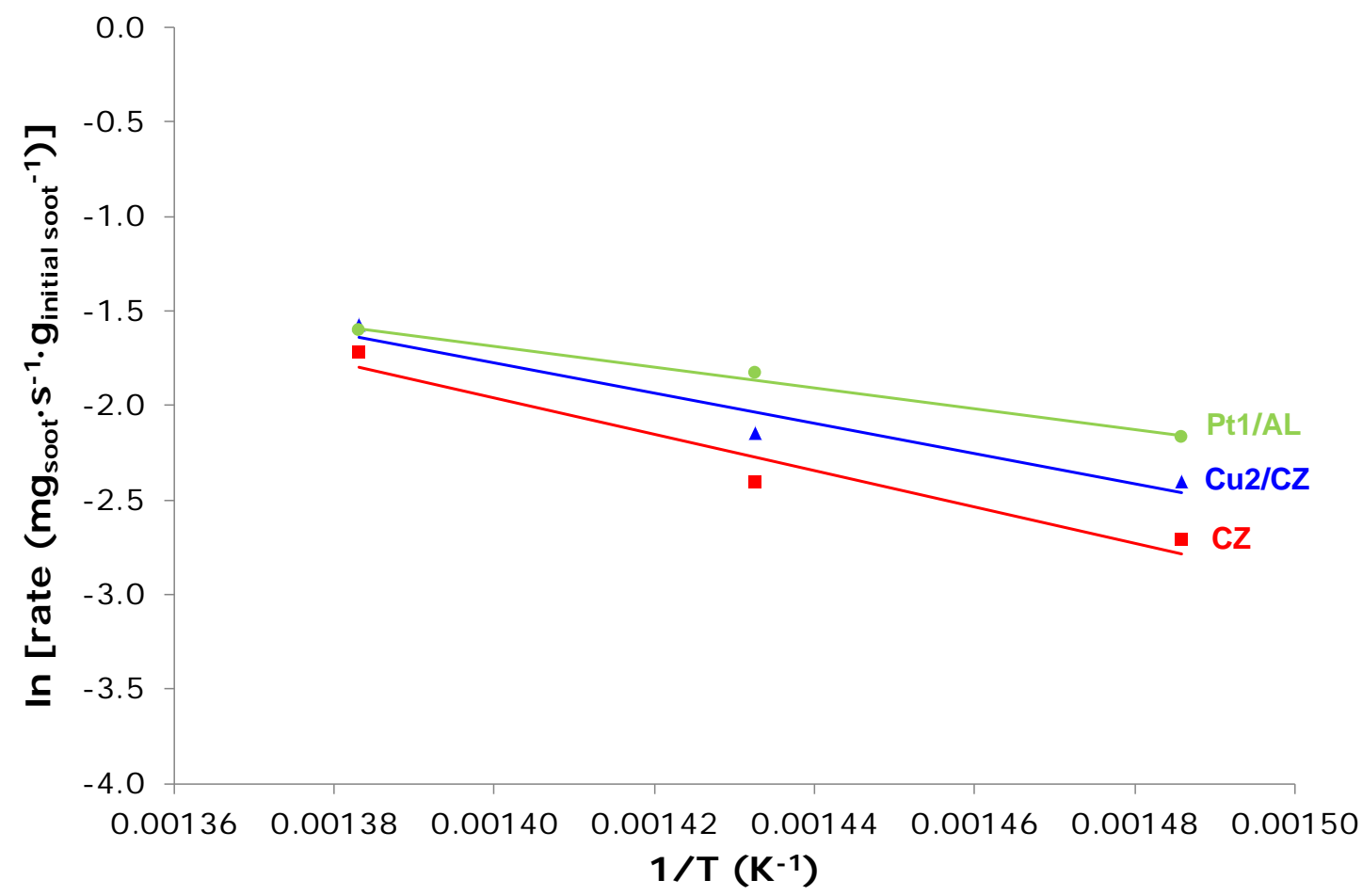

Figure 10. 